\title{
The Standard of Review for Questions of Procedural Fairness
}

\section{Derek McKee}

In 2014, the Supreme Court of Canada affirmed in Mission Institution $\mathrm{v}$ Khela that the standard of review for administrative procedures is correctness. Despite the seeming finality of the decision, case law has demonstrated tensions and ambiguities on the matter. Tracing the origins of this standard, the author demonstrates that this recent call for correctness conflicts with previous calls for deference and with other aspects of contemporary administrative law doctrines. In addressing these conflicting decisions, the author argues that applying the correctness standard to all procedural questions is undesirable as a matter of principle and would lead to unnecessary confusion. The appropriate degree of scrutiny that courts should apply to agencies' procedural choices will vary according to a number of factors, including legislative wording, the general or statute-specific nature of the procedural protections invoked and the type of decisionmaking process at issue. The author argues that courts can better take these factors into account by subjecting agencies' procedural choices to a robust form of reasonableness review.

\footnotetext{
"Assistant Professor, Faculty of Law, Universite de Sherbrooke. I would like to thank Geneviève Cartier, Suzanne Comtois, Paul Daly, David Dyzenhaus, Evan Fox-Decent, Finn Makela and the two anonymous reviewers for comments on earlier drafts. I would also like to thank Samuel Grondin for invaluable research assistance. Mistakes are mine.
} 
Introduction

I. The Origins of Correctness Review of Procedures

A. Recent Changes in Terminology

B. Echoes of Older Concepts: Natural Justice and Jurisdiction

C. Correctness Review of Substance as a Model

II. Tensions in the Procedural Fairness Case Law

III. Is Correctness Review of Procedures Justified?

IV. Dichotomous Standards of Review and the Ambiguous Boundary Between

Process and Substance

A. Adjudicative Fairness and the Duty to Give Redsons

B. Procedural Choices as Decisions

C. Justifications for Dichotomous Standards of Reviewe

V. Toward a Better Approach

Conclusion

\section{Introduction}

In recent years, a subtle shift has occurred in the way Canadian courts talk about administrative procedures. In a series of cases, judges of the Supreme Court of Canada have stated that questions of procedural fairness are to be reviewed according to a "correctness" standard. This formulation originated in a series of obiter dicta by Binnie $J$ and was enshrined in a ratio decidendi by LeBel $\mathrm{J}$ on behalf of a unanimous Court in Mission Institution $v$ Khela. ${ }^{1}$ Correctness review of administrative procedures now appears to be the law in Canada.

Terms such as "correctness" and "standards of review" are borrowed from cases concerning the substantive aspects of administrative decisions. When applied to procedural questions, such terms invite judges to draw analogies between procedural and substantive review. "Correctness review" implies that the analysis of administrative procedures, like substantive correctness review, should be characterized by an absence of deference.

However, the cases on this point contain important tensions and ambiguities. Despite its endorsement of a correctness standard, the Court has also held that reviewing courts should show deference to agencies' procedural choices. Moreover, in many cases there are good reasons for such deference, grounded in legislative intent, as well as in the relative institutional strengths and weaknesses of courts and agencies. I therefore

1. 2014 SCC 24, [2014] 1 SCR 502. 
argue that there is no sound basis for an across-the-board application of a correctness standard to all procedural questions.

I also argue that subjecting all procedural decisions to a correctness standard would establish too great a dichotomy between procedural and substantive decisions. ${ }^{2}$ Such a dichotomy is problematic because the boundary between process and substance is not always clear. The Court's invocation of a correctness standard for procedural questions, combined with the application (since Dunsmuirv New Brunswick ${ }^{3}$ ) of a reasonableness standard for most substantive questions, means that the standard of review is likely to depend on somewhat arbitrary classifications of decisions as procedural or substantive. This state of affairs makes judicial review unpredictable and potentially subject to manipulation.

Paul Daly made a similar argument based on the primacy of legislative intent. He contrasts courts' fidelity to legislative intent in the substantive realm with their relative indifference in the procedural realm. This inconsistency is the focus of his critique as well as the starting point for his reconstructive efforts. I share Daly's concern about courts' heavy reliance on a process/substance dichotomy. However, the inconsistency between procedural and substantive review is secondary to my overall argument.

My main arguments are, first, that the application of a correctness standard to all procedural questions would be inconsistent with previous cases, and second, that such an approach would be inappropriate, regardless of the standard of review applied to substantive questions. There are various reasons why it would be inappropriate. Some of these reasons have to do with respect for legislative intent, as Daly has argued. However, other reasons have to do with the relative institutional capacities of courts and agencies-what Daly has elsewhere referred to as "practical" justifications for deference. ${ }^{4}$ Although external review is important, courts are not always well placed to assess the fairness of agencies' procedures.

I give context to these arguments in Part I by summarizing the recent trend and tracing its origins. I acknowledge that the idea of

2. See Paul Daly, "Canada's Bipolar Administrative Law: Time for Fusion” (2014) 40:1 Queen's LJ 213 [Daly, “Canada's Bipolar Administrative Law”].

3. 2008 SCC 9 at para 63, [2008] 1 SCR 190.

4. Paul Daly, $A$ Theory of Deference in Administrative Law: Basis, Application and Scope (Cambridge, UK: Cambridge University Press, 2012) at 70-136 [Daly, Theory of Deference]. 
procedural correctness review seems to echo the older notion that breaches of natural justice constitute jurisdictional errors. I maintain, however, that this older notion should be abandoned as it provides an incoherent basis for contemporary doctrine. Finally, I explore the meaning of correctness review in the substantive context, explaining what it would mean to subject procedural questions to a correctness standard.

In Part II of this article, I highlight the ambiguities and tensions in the cases on standards of review for procedural questions. I show that the SCC's recent insistence on correctness coexists uneasily with previous calls for deference. In Part III, I explore the formal and institutional arguments that can be offered in support of correctness review of procedures. I show that these arguments are not always persuasive. While correctness review may be justified with regard to certain kinds of procedural norms and administrative processes, it would not be appropriate in all cases. I therefore argue that the judicial application of a correctness standard to all procedural questions is undesirable. In Part IV, I consider the dichotomy between procedural and substantive review in Canadian administrative law. The application of a correctness standard to procedural questions is somewhat incongruous, coming at a time when the Court has generally endorsed a hands-off approach to the review of substance. I argue that the boundary between process and substance is fuzzier than it might seem at first glance and that this ambiguity generates an unfortunate layer of confusion and unpredictability.

This article is primarily intended as a critique. Nevertheless, in Part V, I offer some preliminary thoughts on how courts might resolve the problems I have identified. In my view, courts should acknowledge that the appropriate degree of judicial scrutiny of administrative procedures varies depending on a number of factors, including legislative intent, the source of the procedural norms at issue and the nature of the administrative process under review. I suggest that the best way for courts to consider these factors and to provide appropriate scrutiny of administrative procedures would be through a robust form of reasonableness review. 


\section{The Origins of Correctness Review of Procedures}

\section{A. Recent Changes in Terminology}

In the 2014 Khela case, the SCC signalled a shift in the terminology used to discuss procedural fairness. This case arose from an application for habeas corpus by a federal inmate who was transferred from medium to maximum security. ${ }^{5}$ Justice LeBel, writing for a unanimous Court, invalidated the transfer on procedural fairness grounds. ${ }^{6}$ The warden's decision to transfer Mr. Khela was based on information provided by informants. However, the warden did not disclose these statements to Mr. Khela, nor did she provide him with an adequate summary. In the Court's view, this rendered the decision procedurally unfair. In arriving at this conclusion, LeBel $\mathrm{J}$ declared that "the standard for determining whether the decision maker complied with the duty of procedural fairness will continue to be correctness".

5. Khela, supra note 1 (the main issue before the Court was whether a federal inmate challenging a transfer decision before a provincial superior court could have the substance of the decision reviewed for reasonableness). The Federal Courts Act, RSC 1985, c F-7, $s$ 18(1)(a) confers upon the Federal Court exclusive original jurisdiction to issue an injunction, a writ of certiorari, a writ of prohibition, a writ of mandamus, a writ of quo warranto, or to grant declaratory relief against any federal board, commission or other tribunal. The provincial superior courts retain their inherent jurisdiction to issue writs of habeas corpus, except with regard to members of the Canadian Forces serving outside Canada, as specified in subsection 18(2). In $R v$ Miller, [1985] 2 SCR 613, 24 DLR (4th) 9 , the Court held that federal inmates could nevertheless invoke certiorari in aid of their habeas corpus applications before provincial superior courts. By invoking certiorari in aid of habeas corpus, inmates could bring the full record of the underlying decision before a provincial superior court. However, habeas corpus is confined to questions of legality, and certiorari had traditionally been limited to jurisdictional questions. The issue in Khela was whether provincial superior courts, hearing habeas corpus applications with certiorari in aid, could also consider the reasonableness of the underlying decision. The Court held that they could. Nevertheless, the Court ultimately decided the case on procedural rather than substantive grounds. Khela, supra note 1.

6. Ibid at paras 80,98 .

7. Ibid at para 92.

8. Ibid at para 79 . 
Justice LeBel's reference to continuity is only partly accurate. Khela is in fact the first case in which a majority of the Court, in its ratio decidendi, has invoked a correctness standard for procedural questions. In a number of previous cases, the Court had maintained that "standards of review" were reserved for substantive questions and were simply inapplicable in the context of procedure. As Arbour J put it in Moreau-Bérubé v New Brunswick (Judicial Council), with regard to questions of procedural fairness, "no assessment of the appropriate standard of judicial review" is necessary; instead, a court should simply assess "the procedures and safeguards required in a particular situation". ' Justice Binnie confirmed this point in CUPE $v$ Ontario (Minister of Labour)-the retired judges case-declaring that " $[\mathrm{t}] \mathrm{he}$ content of procedural fairness goes to the manner in which the Minister went about making his decision, whereas the standard of review is applied to the end product of his deliberations." ${ }^{10}$

In the early 2000s, it was widely accepted that standards of review were inapplicable to procedural questions. ${ }^{11}$ Aside from case law, confirmation of this approach is found in British Columbia's Administrative Tribunals Act. ${ }^{12}$ Sections 58 and 59 of that statute codify the applicable standards of review for different kinds of administrative decisions. Substantive questions are subject to 1990s-style correctness, reasonableness and patent unreasonableness standards, depending on the nature of the question and the presence or absence of a privative clause.

However, procedural questions are set apart. Whether or not a tribunal has a privative clause, "questions about the application of common law rules of natural justice and procedural fairness must be decided having regard to whether, in all of the circumstances, the tribunal acted fairly". ${ }^{13}$

9. 2002 SCC 11 at para 74, [2002] 1 SCR 249 [Moreau-Bérubé].

10. 2003 SCC 29 at para 102, [2003] 1 SCR 539.

11. See e.g. London (City) v Ayerswood Development Corp et al (2002), 167 OAC 120 at para 10, 34 MPLR (3d) 1; Québec (PG) c Germain Blanchard ltée, 2005 QCCA 605 at para 106, 52 Admin LR (4th) 1.

12. SBC 2004, c 45 .

13. Ibid, s 58(2)(b) (this section applies to tribunals whose enabling statutes contain privative clauses). Identical wording is used in section $59(5)$ with regard to tribunals whose enabling statutes contain no privative clauses. Ibid, s 59(5). 
Indeed, whether or not a tribunal has a privative clause, procedures are expressly excluded from the scope of correctness review. ${ }^{14}$

Subsequent confirmation of the exclusively substantive orientation of "standards of review" is found in Dunsmuir, in which Bastarache and LeBel JJ, writing for the majority, rechristened the "pragmatic and functional approach" to substantive issues as simply "the standard of review analysis". ${ }^{15}$ Justices Bastarache and LeBel dealt with procedural issues separately, without referring to standards of review. However, the Khela formulation is not entirely new. It was foreshadowed in a series of statements by Binnie J. Over the course of a decade-sometimes in obiter, sometimes in dissenting or concurring reasons-Binnie J introduced the language of correctness review to the Court's procedural fairness jurisprudence.

The first such statement can be found in Ellis-Don Ltd v Ontario (Labour Relations Board). ${ }^{16}$ Justice Binnie, in dissent, cited a passage from Donald Brown and John Evans' loose-leaf treatise to support the application of a correctness standard:

The respondent union argues that the Board's decision should be set aside only if it is "patently unreasonable". This presupposes that the error was made within the Board's jurisdiction. The appellant contends that the panel of the Board lost jurisdiction when it called for a full Board meeting to discuss what it regards as a question of fact. Compliance with the rules of natural justice is a legal issue. The standard of review is correctness as noted in D. J. M. Brown and J. M. Evans, Judicial Review of Administrative Action in Canada (loose-leaf), vol. 2, at para. 14:2300, pp. 14-14 and 14-15:

[W] hether the administrative decision-maker has breached the rules of natural justice or the duty of procedural fairness by failing to permit any, or adequate, participation by the person concerned will usually be assessed on the basis of "correctness." And the presence of a privative clause will be of no consequence in this regard.

I think this is a correct statement of the law. ${ }^{17}$

14. See ibid, ss 58(2)(c), 59(1). Of course, the British Columbia Administrative Tribunals $A c t$ is not a source of the common law of judicial review. However, this legislation appears to reflect dominant understandings of administrative law in the early 2000 s.

15. Supra note 3 at para 63.

16. 2001 SCC 4, [2001] 1 SCR 221 [Ellis-Don].

17. Ibid at para 65 .

D. McKee 
Justice Binnie continued on this theme in his concurring reasons in Dunsmuir, signed by him alone. In these reasons, Binnie J listed procedural fairness among the types of questions that should attract a correctness standard. Justice Binnie reasoned that "a fair procedure is said to be the handmaiden of justice" and concluded that "the courts have the final say" on such matters. ${ }^{18}$

In Canada (Citizenship and Immigration) $v$ Khosa just a year later, Binnie J had the chance to reiterate his views on behalf of a majority of the Court. ${ }^{19}$ Analyzing the relationship between standards of review and the grounds of judicial review provided for in the Federal Courts Act, Binnie J declared that "Dunsmuir says that procedural issues (subject to competent legislative override) are to be determined by a court on the basis of a correctness standard of review" ${ }^{20}$ Here, Binnie J appears to have been citing his own (solo) concurring reasons in Dunsmuir rather than those of the majority, although his failure to cite a specific passage of the judgment makes this difficult to verify. Nor did Binnie J provide any explanation or justification for this remark; it appears that it was made in passing - and in obiter, since procedural fairness was not at issue in Khosa.

Two years later, in Alberta (Information and Privacy Commissioner) $v$ Alberta Teachers' Association, Binnie J insisted on the same point, once again (as in Dunsmuir) writing alone. ${ }^{21}$ Discussing the circumstances in which a correctness or a reasonableness standard should apply, Binnie J stated that "[o]n issues of procedural fairness or natural justice, for example, the courts should not defer to a tribunal's view of the extent to which its 'home statute' permits it to proceed in what the courts conclude is an unfair manner." ${ }^{22}$

During his thirteen years at the Court, Binnie J thus declared four times that a correctness standard should apply to procedural questions. On only one of these occasions, however-in Khosa-did he do so on behalf of a majority of the Court, although this declaration was made in passing only and based on uncertain authority.

\footnotetext{
18. Dunsmuir, supra note 3 at para 129.

19. 2009 SCC 12, [2009] 1 SCR 339 [Khosa].

20. Ibid at para 43 [citation omitted].

21. 2011 SCC 61, [2011] 3 SCR 654 [Alberta Teachers' Association].

22. Ibid at para 82 .
} 
Nevertheless, Binnie J's statements were influential. Some lower courts accepted these obiter as authoritative statements of the law. ${ }^{23}$ This is partly because Dunsmuir was a watershed case in Canadian administrative law. Justices Bastarache and LeBel's majority reasons in Dunsmuir overhauled the methodology for determining the standard of review for questions of substance. Although Bastarache and LeBel JJ's reasons do not discuss procedural fairness in terms of standards of review, Binnie J's concurring reasons have been interpreted as a companion to these majority reasons.

Although LeBel J cited no authority for his declaration in Khela, his opinion appears to be a continuation (and a confirmation) of this series of pronouncements by Binnie J. Khela seems significant partly because it is the first Supreme Court decision in which a judge other than Binnie J has used the terminology of correctness review in relation to procedural questions. It shows that other judges of the Court have embraced Binnie J's formulation and that they have been willing to apply it, even after Binnie J's retirement from the Court. ${ }^{24}$

According to some judges and lawyers, LeBel J's formulation in Khela has dispelled any uncertainty about the standard of review for procedural questions. For example, in Air Canada v Greenglass, Nadon JA cited Khela for the proposition that "there can be no doubt that these [procedural] issues must be assessed against a standard of correctness". ${ }^{25}$ However, as I will explain in Part IV, below, a closer look at LeBel J's analysis reveals certain ambiguities. Justice LeBel also held that a warden deciding to withhold information related to a transfer decision should be "entitled to a margin of deference". ${ }^{26}$ While ostensibly settling the issue, Khela also reveals underlying tensions, as I shall endeavour to demonstrate below in Part II.

23. See e.g. Irving Shipbuilding Inc $v$ Canada (Attorney General), 2009 FCA 116 at para 26, [2010] 2 FCR 488 [Irving Shipbuilding]; Economical Mutual Insurance Company v British Columbia (Information and Privacy Commissioner), 2013 BCSC 903 at para 51, 55 Admin LR (5th) 313.

24. It remains to be seen whether other judges of the Court adhere to this approach despite LeBel J's subsequent retirement.

25. 2014 FCA 288 at para 26, 468 NR 184 [citation omitted].

26. Khela, supra note 1 at para 89.

D. McKee 


\section{B. Echoes of Older Concepts: Natural Justice and Jurisdiction}

The Court's articulation of a correctness standard for questions of procedural fairness appears to echo an older doctrine. For most of the twentieth century, Canadian courts, like their British counterparts, held that breaches of natural justice constituted jurisdictional errors. The notion that questions of procedural fairness are reviewable on a correctness standard appears to follow the same model, with "procedural fairness" sitting in for "natural justice" and "correctness" for "jurisdiction". ${ }^{27}$ However, as I explain in this Part, there is no inherent link between natural justice and jurisdiction; the link between these two concepts was artificial and historically contingent. Indeed, the Court has recognized the artificiality of the natural justice/jurisdiction nexus several times in the late-twentieth century. Moreover, the newer concepts are not quite equivalent to the older ones, and must be evaluated on their own terms. For these reasons, the older doctrine should not be used as a basis for contemporary administrative law.

Mid-twentieth-century Canadian courts often held that breaches of natural justice were to be treated as jurisdictional errors. The SCC confirmed the jurisdictional nature of natural justice questions in a series of cases in the 1950s and 1960s. Most of these cases arose from decisions of labour boards with regard to union certification. Such decisions were typically protected by strong privative clauses.

In the leading case, Toronto Newespaper Guild, Local $87 v$ Globe Printing Co, an employer alleged that a number of workers had resigned from the union prior to the board's certification decision..$^{28}$ If these resignations had indeed occurred, they would have placed the union in a minority position and made it ineligible for certification. The employer asked the Board for permission to cross-examine the union's secretary with regard to membership. The Board refused. A majority of the Court ultimately held that this refusal amounted to a breach of natural justice. ${ }^{29}$

27. For contemporary examples of the persistence of the older concepts, see Mastrocola $c$ Autorité des marchés financiers, 2010 QCCS 1243 at para 31, 4 Admin IR (5th) 1; Volochay $v$ College of Massage Therapists of Ontario, 2011 ONSC 2225, 30 Admin IR (5th) 327, rev'd 2012 ONCA 541,111 OR (3d) 561.

28. [1953] 2 SCR 18, [1953] 3 DLR 561 [Globe Printing cited to SCR].

29. See ibid at 30-38. For an additional example, see Quebec Labour Relations Board $v J$ Pascal Hardware Co Ltd, [1965] BR 791, 1965 CarswellQue 193 (WL Can) (CA). 
The majority specified, moreover, that such a breach amounted to a jurisdictional error, declaring that the board had "refused to enter upon the question" and had thus "declined jurisdiction"..$^{30}$

The idea that breaches of natural justice could constitute jurisdictional errors was also invoked to protect workers' collective bargaining rights. In a decision issued concurrently with Globe Printing, the Court held that the Quebec Labour Relations Board had "acted without jurisdiction" when it had decertified a union at an employer's request without giving the union a chance to be heard. ${ }^{31}$ On one occasion, the Court also assimilated natural justice to jurisdictional concerns outside the context of labour relations. In Board of Health, Saltfleet Township $v$ Knapman, the Court overturned the decision of a local board of health that had ordered the evacuation of rental properties without first hearing from the landlord. ${ }^{32}$ Mid-twentieth-century Canadian courts thus explained the "jurisdictional" nature of natural justice concerns by reformulating them in substantive terms. It was held that a refusal to receive certain evidence could amount to a refusal to verify whether all of the statutory preconditions for the exercise of jurisdiction were in place, and thus a "declining" of jurisdiction.

By the mid-1970s, the notion that breaches of natural justice constituted a species of jurisdictional error had sufficiently crystallized that Laskin CJC could declare in the pages of a United Kingdom law journal that

[o]n one issue, Canadian judges have been unanimous in refusing to pay heed to privative clauses, whatever be their differences on other issues, and that is where natural justice is involved. There is agreement that natural justice goes to jurisdiction, whatever be the stage of the proceeding at which there is a failure to observe it. ${ }^{33}$

30. See Globe Printing, supra note 28 at 35.

31. Alliance des Professeurs Catholiques de Montréal v Quebec Labour Relations Board, [1953] 2 SCR 140 at 157, Kerwin J, 163, Rand J, 169, Fauteux J, [1953] 4 DLR 161.

32. [1956] SCR 877, 6 DLR (2d) 81.

33. See Bora Laskin, "English Law in Canadian Courts since the Abolition of Privy Council Appeals" (1976) 29:1 Current Leg Probs 1 at 16-17. In the same passage, Laskin CJC acknowledged that

[o]f course, this consensus merely identifies the problem; it does not resolve the difficulties involved in determining what natural justice means under particular legislation and in a particular proceeding, and whether there has been such a 
Indeed, as late as the 1980 s and 1990 s, the Court continued to treat breaches of natural justice as jurisdictional errors, at least in the context of labour arbitrators hearing the grievances of individual workers in a collective bargaining context. ${ }^{34}$

Despite the apparent solidity of this doctrine, the link between natural justice and jurisdiction is the product of a historical contingency. The two concepts originated at different times and were meant to serve different purposes.

The concept of jurisdiction in the law of judicial review can be traced back to struggles for constitutional supremacy in England during the late-seventeenth century. ${ }^{35}$ During the Stuart Restoration, Parliament began to assign a wide variety of functions to justices of the peace and other minor officials. Moreover, Parliament began to enact privative clauses, statutory provisions exempting the decisions of certain officials from judicial review. ${ }^{36}$ These moves raised the hackles of the Court of King's Bench, whose judges claimed the power to review the actions of all state officials. These judges thus began to expand the writ of certiorari, which previously had a rather restricted use, into a general mechanism for judicial review. Moreover, the Court of King's Bench gradually reframed the availability of certiorari in terms of the concept of jurisdiction. This concept enabled the court to circumvent privative clauses. In essence, the court held that Parliament could not have intended officials to be the ultimate arbiters of their own jurisdictional boundaries because this would, in effect, allow them to exceed the intended boundaries.

failure to observe it as to justify the quashing of a decision. There is, generally, a reluctance to invoke the discretionary side of certiorari or its equivalents in order to deny relief where there has been a failure to accord natural justice.

Ibid.

34. See e.g. Roberval Express Ltée v Transport Drivers, Warehousemen and General Workers Union, Local 106, [1982] 2 SCR 888, 144 DLR (3d) 673 (“[a] refusal to hear admissible and relevant evidence is so clear a case of excess or refusal to exercise jurisdiction that it needs no further comment" at 904); Universitédu Québec à Trois-Rivières c Larocque, [1993] 1 SCR 471,101 DLR (4th) 494 ("[a] breach of the rules of natural justice is regarded in itself as an excess of jurisdiction and consequently there is no doubt that such a breach opens the way for judicial review" at 490).

35. See Amnon Rubinstein, Jurisdiction and Illegality: A Study in Public Law (Oxford: Clarendon Press, 1965) at 61-74.

36. See ibid at 71-72. 
The writ of certiorari thus came to be associated with jurisdictional review, and was held to be applicable only where lower courts and state officials had exceeded their jurisdiction. ${ }^{37}$

As Roderick Macdonald pointed out, natural justice and its component principles-audi alterem partem and nemo judex in sua causahave their own distinct history. ${ }^{38}$ The prominence of these concepts in UK administrative law dates from the late-nineteenth century. It was at that time in Britain that Parliament began to assign fact-finding, decision-making and regulatory powers to a wide range of boards and commissions. UK courts then began to imply procedural requirements for these bodies. ${ }^{39}$ The courts formulated the principles of natural justice as they strove to develop a theory of adjudication and to assert their control over inferior tribunals.

However, in order to control the procedures used by boards and commissions, UK courts had to circumvent privative clauses. This meant assimilating the concept of natural justice to the concept of jurisdiction. For example, it was held that an agency's attempt to limit the evidence before it-a refusal to follow court-like procedures-could be construed as refusal to decide a substantive question: "declining to enter upon an inquiry on which [it] was bound to enter" 40 and thus a "declining of jurisdiction". ${ }^{41}$ Nineteenth-century UK courts thus circumvented privative clauses by reframing natural justice in terms of substantive concerns and characterizing these concerns as "jurisdictional". The treatment of natural justice as a jurisdictional issue is a product of this historical contingency.

Indeed, the artificiality of the natural justice/jurisdiction nexus was sometimes recognized by late-twentieth-century Canadian courts. These courts recognized that natural justice did not have to be treated as a jurisdictional issue. The flexibility of the concept of jurisdiction made it possible for judges to ignore or overlook minor procedural problems. On three occasions during the 1950s and 1960s, the SCC held that breaches of

37. See e.g. ibid at 71-74. See also SA de Smith, Judicial Review of Administrative Action, 3d ed (London UK: Stevens \& Sons, 1973) at 512-13.

38. RA Macdonald, "Judicial Review and Procedural Fairness in Administrative Law: I" (1980) 25:4 McGill LJ 520 at 530-31, 536-37.

39. The classic case is Cooper v Wandsworth Board of Works (1863), 143 ER 414 (HI) [Cooper].

40. RvMarsham (1891), [1892] 1 QB 371 at 375, Lord Halsbury (Eng).

41. Ibid at 378, Lord Esher. 
natural justice were insufficiently serious as to entail a loss of jurisdiction. ${ }^{42}$ During the 1970s, the Court also distinguished natural justice concerns from subject-matter jurisdiction in the strict sense. For example, in a 1977 dissenting opinion, Spence J identified the natural justice/jurisdiction nexus as "a mere matter of technique in determining the jurisdiction of the Court to exercise the remedy of certiorari" ". Likewise, Dickson J, as he then was, noted in obiter in Nurses Association that natural justice was not a matter of "jurisdiction in the narrow sense of authority to enter upon an inquiry". ${ }^{44}$ Instead, a breach of natural justice was something that could occur during the course of an inquiry that would take "the exercise of [the agency's] powers outside the protection of the privative or preclusive clause". ${ }^{5}$ In addition, in Harelkin $v$ University of Regina, Beetz J noted in obiter that a breach of natural justice, while "akin' to a jurisdictional error", did not "entail the same type of nullity as if there had been a lack of jurisdiction". ${ }^{46}$ The identification of natural justice as a jurisdictional issue is therefore arbitrary. These concepts lack any underlying unity. It would be incoherent and misleading to base contemporary administrative law on the idea that a breach of natural justice "goes to jurisdiction".

42. See Labour Relations Board v Traders' Service Ltd, [1958] SCR 672 at 677-78, 15 DLR (2d) 305; Bakery and Confectionery Workers International Union of America, Local No 468 v White Lunch Ltd, [1966] SCR 282 at 295-96, 56 DLR (2d) 193; Komo Construction Inc c Commission des Relations de Travail du Québec (1997), [1968] SCR 172 at 175, 1 DLR (3d) 125 [Komo Construction].

43. Canada Labour Relations Board v Transair Ltd (1976), [1977] 1 SCR 722 at 747, 67 $\operatorname{DLR}(3 \mathrm{~d}) 421$.

44. Service Employees' International Union, Local No $333 v$ Nipawin District Staff Nurses Association, [1975] 1 SCR 382 at 389, 41 DLR (3d) 6.

45. Ibid. The Court stated that:

A tribunal may, on the one hand, have jurisdiction in the narrow sense of authority to enter upon an inquiry but, in the course of that inquiry, do something which takes the exercise of its powers outside the protection of the privative or preclusive clause. Examples of this type of error would include acting in bad faith, basing the decision on extraneous matters, failing to take relevant factors into account, breaching the provisions of natural justice or misinterpreting provisions of the Act so as to embark on an inquiry or answer a question not remitted to it.

Ibid at 389. Note that Dickson J was paraphrasing language used by Lord Reid in Anisminic $v$ Foreign Compensation Commission, [1968] UKHL 6 [Anisminic].

46. [1979] 2 SCR 561 at 585, 96 DLR (3d) 14. 
Moreover, natural justice and jurisdiction have both waned in importance since the 1970s, and the concepts that have replaced them are not quite equivalent. The Court's recognition of a general duty of procedural fairness in Nicholson v Haldimand-Norfolk Regional Police Commissioners has made the notion of natural justice somewhat redundant. ${ }^{47}$ Indeed, in Martineau v Matsqui Institution Disciplinary Board, Dickson CJC opined that "[i]n general, courts ought not to seek to distinguish between the two concepts, for the drawing of a distinction between a duty to act fairly, and a duty to act in accordance with the rules of natural justice, yields an unwieldy conceptual framework." ${ }^{38}$ Contemporary Canadian courts still invoke the rules of natural justice, and the classic natural justice principles of audi alterem partem and nemo judex in sua causa continue to structure courts' analysis of procedural fairness. But a flexible, context-sensitive notion of procedural fairness has become the dominant concept.

A similar point can be made for jurisdiction. In the landmark case CUPE v New Brunswick Liquor Corporation, Dickson J, as he then was, commented on the difficulty of isolating "jurisdictional" issues and warned that "[t]he courts, in my view, should not be alert to brand as jurisdictional, and therefore subject to broader curial review, that which may be doubtfully so." ${ }^{* 9}$ In Pushpanathan v Canada (Minister of Citizenship and Immigration), the Court all but abolished the formal concept of jurisdiction, stating that a "jurisdictional question" was simply a question calling for the application of a correctness standard, depending on the outcome of the four-factor pragmatic and functional approach..$^{50}$ The Court reintroduced a narrow concept of jurisdiction in Dunsmuir, ${ }^{51}$ but the Court has since expressed misgivings about this category. ${ }^{52}$

It must be acknowledged that the Khela formulation appears to restate an old (and at one point, well-established) administrative law doctrine. However, it would be a mistake to treat this older doctrine as a precedent for correctness review of procedures. The older doctrine was historically

47. (1978), [1979] 1 SCR 311, 88 DLR (3d) 671 [Nicholson cited to SCR].

48. (1979), [1980] 1 SCR 602 at 629, 106 DLR (3d) 385 [Martineau].

49. Canadian Union of Public Employees, Local 963 vew Brunswick Liquor Corp, [1979] 2 SCR 227 at 233, 25 NBR (2d) 237.

50. [1998] 1 SCR 982 at para 28, 160 DLR (4th) 193 [Pushpanathan]. But see Chieuv Canada (Minister of Citizenship and Immigration), 2002 SCC 3 at para 24, [2002] 1 SCR 84.

51. Supra note 3 at para 59.

52. See Alberta Teachers' Association, supra note 21 at paras 33-43, Rothstein J. 
contingent and contested and its component parts have been replaced by newer (and different) concepts. In order to understand the Court's recent formulation, we must examine it on its own terms.

\section{Correctness Review of Substance as a Model}

What does it mean to say that administrative procedures must be assessed according to a correctness standard? The Court initially developed the correctness standard for substantive questions. Substantive correctness review therefore provides the obvious model for procedural correctness review. In brief, correctness review is characterized by an absence of deference. It is usually (but not exclusively) applied to legal questions. The Court has stated that, when undertaking correctness review of substance, a reviewing court should conduct its own analysis to determine the right answer to the substantive question at hand. ${ }^{53}$ It should then see whether the agency arrived at the same answer. If not, the court should hold the agency's decision to be incorrect, and thus invalid. ${ }^{54}$

This analytic process can be contrasted with that of reasonableness review. When reviewing the reasonableness of administrative decisions, courts start by examining the reasons given by the administrative decision maker. They ask whether these reasons provide an adequate basis for the decision. ${ }^{55}$ When undertaking reasonableness review, courts are meant to grant a certain degree of deference to the agency's determination. A court may hold an administrative decision to be reasonable even if the court would have resolved the matter in some other way. The reasonableness standard is based on the recognition that questions of public administration do not always yield a single best answer..$^{56}$

Paul Daly has argued that the concepts of deference and correctness review need not be mutually exclusive. Daly distinguishes between "epistemic deference" and "doctrinal deference". He explains that courts employ epistemic deference when they accord a certain amount of weight to an agency's perspective. Doctrinal deference, on the other

53. See Law Society of New Brunswick v Ryan, 2003 SCC 20 at para 50, [2003] 1 SCR 247 [Ryan].

54. See Dunsmuirv New Brunswick, supra note 3 at para 50.

55. See Ryan, supra note 53 at paras $49,54-56$.

56. See ibid at para 51; Dunsmuir v New Brunswick, supra note 3 at para 47. 
hand, requires courts to recognize that agencies have their own spheres of authority, protected from judicial intervention to some extent. ${ }^{57}$ While doctrinal deference implies some form of reasonableness review, Daly suggests that a certain amount of epistemic deference may be compatible with correctness review. A court applying a correctness standard could consider the agency's perspective just as it would consider any other relevant matter. ${ }^{58}$

While I agree with Daly in principle, I would suggest that Canadian courts have generally understood correctness review to be stricter than what he describes-involving a complete absence of deference. When applying a correctness standard, courts have often given little, if any, weight to agencies' perspectives. They have rather treated correctness review as an opportunity to substitute their own views for those of the agency. In Rogers Communications Inc $v$ Society of Composers, Authors and Music Publishers of Canada, for example, Rothstein J applied a correctness standard, upholding the Copyright Board's decision as correct, in part. ${ }^{59}$ In so doing, Rothstein $\mathrm{J}$ made only passing reference to the Copyright Board's interpretive approach. ${ }^{60}$ Likewise, in McCormick $v$ Fasken Martineau DuMoulin LLP, applying a correctness standard, Abella J referred to the British Columbia Human Rights Tribunal's reasoning only to point out its flaws. ${ }^{61}$

Courts have most often applied a correctness standard to questions of law. Substantive correctness review is descended from jurisdictional review, as practiced by Canadian courts in the 1960s and 1970s. ${ }^{62}$ Under the dominant approach to judicial review at that time, a correctness standard was applied to all questions that fell outside the agency's jurisdiction (and thus outside the protection of the privative clause, if there was one). Courts undertaking jurisdictional review therefore emphasized questions of statutory interpretation; they saw themselves as policing the boundaries of agencies' legislative mandates. The association of correctness review

57. See Daly, Theory of Deference, supra note 4 at 7-13.

58. See ibid at $138-39$.

59. 2012 SCC 35, [2012] 2 SCR 283 [Rogers].

60. See ibid at paras $27-28$.

61. 2014 SCC 39 at para 44, [2014] 2 SCR 108.

62. See e.g. Metropolitan Life Insurance Co v International Union of Operating Engineers, Local 796, [1970] SCR 425, 11 DLR (3d) 336; Bell v Ontario Human Rights Commission, [1971] SCR 756, 18 DLR (3d) 1. 
with legal questions is even clearer in the UK, where, since 1969, the concept of jurisdictional error (and hence correctness review) has been expanded to encompass almost all errors of law..$^{63}$

From the late 1980s to the early 2000s, under the Court's "pragmatic and functional approach," the law/fact distinction was one of four factors used to determine the standard of review for substantive questions (along with the presence or absence of a privative clause, the agency's expertise vis-à-vis that of the reviewing court, and the purpose of the statute). ${ }^{64}$ The characterization of an issue as "purely" legal militated for a higher standard of review under the pragmatic and functional approach. ${ }^{65}$ Likewise, the identification of a "mixed" question of law and fact would in principle prompt a court to determine whether it contained more factual or legal elements, with corresponding effects on the standard of review. ${ }^{66}$ However, the law/fact distinction was not determinative, and the standard of review could depend on other factors. ${ }^{67}$ Nevertheless, courts tended to undertake correctness review when dealing with "general" questions of law, ${ }^{68}$ including constitutional questions. ${ }^{69}$

63. This development began with Anisminic, supra note 45, in which the House of Lords adopted an expansive approach to jurisdictional error. The House of Lords later modulated the application of this approach according to the type of body subject to review, applying it more strictly to administrative agencies and less strictly to inferior courts. See Re Racal Communications Ltd, [1980] UKHL 5. In 1993, the House of Lords confirmed the Anisminic approach to errors of law, but qualified it somewhat by specifying that decisions should only be overturned for errors on "relevant" points of law-i.e., errors with an impact on the decision. See $R v$ Hull University Visitor, ex parte Page, [1992] UKHL 12. In the same year, the House of Lords also held that courts should grant a margin of deference to agencies in their interpretation of vague statutory standards. See $R v$ Monopolies and Mergers Commission, ex parte South Yorkshire Transport Ltd, [1993] 1 All ER 289 (HL).

64. See e.g. Pushpanathan, supra note 50 at paras 29-38.

65. See e.g. ibid at para 37; Dr Q $v$ College of Physicians and Surgeons of British Columbia, 2003 SCC 19 at para 34, [2003] 1 SCR 226 [Dr Q]; Barrie Public Utilities v Canadian Cable Television Assn, 2003 SCC 28 at para 16, [2003] 1 SCR 476.

66. See e.g. $\operatorname{Dr} Q$, supra note 65 at para 34.

67. See e.g. Pasiechnyk v Saskatchewan (Workers' Compensation Board), [1997] 2 SCR 890, 149 DLR (4th) 577 (in which the presence of a full privative clause and other factors led the Court to apply a patent unreasonableness standard to a question of law). See also Baker $\checkmark$ Canada (Minister of Citizenship and Immigration), [1999] 2 SCR 817 at para 58, 174 DLR (4th) 193 [Baker].

68. See e.g. Canada (Attorney General) v Mossop, [1993] 1 SCR 554, 100 DLR (4th) 658.

69. See e.g. Nova Scotia (Workers' Compensation Board) v Martin; Nova Scotia (Workers' 
Dunsmuir restored the pre-eminence of the law/fact distinction in the determination of the standard of review. In Dunsmuir, the Court made reasonableness the default standard for questions of fact as well as "questions where the legal and factual issues are intertwined with [sic] and cannot be readily separated" ${ }^{70}$ Dunsmuir also established reasonableness as the appropriate standard for certain legal questions (i.e., questions of the interpretation of the agency's home statute). Since Dunsmuir, the correctness standard is reserved for a limited set of legal questions: constitutional questions, questions of jurisdiction, questions of general law, and questions of overlapping statutory mandates. ${ }^{71}$ In contemporary Canadian administrative law, the availability of correctness review thus remains linked to the legal (as opposed to factual) nature of the question, although the standards have shifted.

The legal nature of the questions at stake is at the heart of the justifications typically offered for substantive correctness review. Substantive correctness review is often informed by formal rule of law concerns. By applying a strict standard to agency decisions, courts strive to ensure the coherence and integrity of the legal system as a whole. The Court has expressed this concern most clearly in its prescription for correctness review of constitutional question ${ }^{72}$ and "general" questions of law. ${ }^{73}$ Seen in this light, courts reviewing administrative decisions perform a function analogous to that of appellate courts reviewing lower court decisions: standardizing legal interpretation (and therefore granting no deference). ${ }^{74}$ As a majority of the Court declared in Dunsmuir, correctness review "avoids inconsistent and unauthorized application of law". ${ }^{75}$

Diceyan constitutional theory takes this argument a step further, emphasizing judges' unique constitutional role. According to A.V. Dicey, the rule of law includes the baseline principle of equality before the law, meaning that state officials are subject to the "ordinary" law, except as otherwise specified by statute. When officials exceed their statutory powers, they are on the same footing as any other citizen, having

Compensation Board) v Laseur, 2003 SCC 54, [2003] 2 SCR 504.

70. Dunsmuir v New Brunswick, supra note 3 at para 53.

71. Ibid at paras $58-61$.

72. See ibid at para 58 .

73. See ibid at para 60.

74. See e.g. Housen $v$ Nikolaisen, 2002 SCC 33 at paras 8-10, [2002] 2 SCR 235.

75. Supra note 3 at para 50. 
interfered with others' rights, and may be held personally liable before the "ordinary" courts. ${ }^{76}$ According to this theory, the judiciary must resolve any ambiguities in agencies' mandates without regard to administrators' own assessments of their powers.

Substantive correctness review has also been justified in terms of the relative institutional capacities of courts and agencies. Courts have sometimes insisted on correctness review on the grounds that judges are the foremost experts on legal questions. ${ }^{77}$ In mainstream contemporary Canadian administrative law opinion, this institutional argument survives only in a qualified form. It is acknowledged that specialized administrative agencies may be more expert than generalist courts with regard to certain legal questions, especially those involving the interpretation of their "home" statutes. ${ }^{78}$ Nevertheless, the "legal" nature of a question remains an argument against deference. ${ }^{79}$

Substantive correctness review, as described here, provides the prototype for correctness review ingeneral. The application of a correctness standard to procedural questions would presumably proceed along similar lines. Courts would grant no deference to agencies in procedural matters. However, as I shall endeavour to show in the following Parts, there are doctrinal as well as theoretical reasons for skepticism about such an approach.

\section{Tensions in the Procedural Fairness Case Law}

As I have already noted, Khela contains an ambiguity. While enshrining a correctness standard for procedural questions, LeBel J also invoked the possibility of a "margin of deference". In fact, this ambiguity is symptomatic of deeper tensions in the procedural fairness case law.

76. AV Dicey, Introduction to the Study of the Law of the Constitution, 10th ed (London UK: Macmillan, 1961) at 193-94.

77. See e.g. Pushpanathan, supra note 50 at para 37; Dunsmuir v Nere Brunswick, supra note 3, Deschamps J ("superior courts have a core expertise to interpret questions of law" at para 162).

78. Dunsmuir v New Brunswick, supra note 3 at paras 54-55.

79. See e.g. Rogers, supra note 59 at para 20. 
Despite the Court's recent insistence on a correctness standard, it has also endorsed judicial deference on a number of occasions.

In the following discussion, I am mainly concerned with common law procedural requirements. ${ }^{80}$ While legislators have sometimes stipulated procedures for agencies to follow, many of the requirements of procedural fairness (and formerly, natural justice) have been generated by courts themselves. The classic statement in Cooper $v$ Wandsworth Board of Works, that the "justice of the common law will supply the omission of the legislature," still informs courts' approach to procedural fairness. ${ }^{81}$ The judge-made requirements of natural justice or procedural fairness are understood as a set of default rules. Legislators may derogate from these rules, but only if they do so expressly. ${ }^{82}$ Otherwise, courts will imply the procedural requirements derived from common law.

As noted in Part I, above, UK judges in the late-nineteenth century began to apply the rules of natural justice to newly created administrative agencies. In the early-twentieth century, however, British judges nevertheless adopted a posture of restraint with regard to administrative procedures. 'This trend began with the House of Lords' decision in Local Government Board $v$ Arlidge, ${ }^{83}$ in which Lord Shaw opined that it was inappropriate to impose court-like procedures on government agencies. This restraint eventually crystallized in the rule that only judicial or quasijudicial functions were subject to review for conformity with the rules of natural justice. ${ }^{84}$ Moreover, the House of Lords held that an agency exercising administrative functions was "master of its own procedure". ${ }^{85}$ Canadian courts followed the lead of British courts in this regard. ${ }^{86}$

80. For the purposes of this article, I am focusing on statutory and common law procedural requirements. For the sake of brevity and clarity, I have chosen to bracket the question of constitutionalized procedures (such as those required by section 7 of the Canadian Charter of Rights and Freedoms, Part I of the Constitution Act, 1982, being Schedule B to the Canada Act 1982 (UK), 1982, c 11).

81. Cooper, supra note 39 at 420 , Lord Byles.

82. See e.g. Knight v Indian Head School Division No 19, [1990] 1 SCR 653 at 667-81, 69 DLR (4th) 489 [Knight]; Ocean Port Hotel Ltd v British Columbia (General Manager, Liquor Control and Licensing Branch), 2001 SCC 52 at para 27, [2001] 2 SCR 781.

83. (1914), [1915] AC 120 (Eng). See generally de Smith, supra note 37 at 142-51.

84. See $R v$ Electricity Commissioners, ex parte London Electricity Joint Committee Co Ltd (1920), [1924] $1 \mathrm{~KB} 171$ (Eng).

85. General Medical Council v Spackman, [1943] AC 627 at 634 (Eng), Viscount Simon.

86. See e.g. Komo Construction, supra note 42, Pigeon J (“[ $t]$ out en maintentant le principe 
At first glance, such self-restraint on the part of classical liberal judges, hostile to the expanding administrative state, seems rather surprising. However, as David Dyzenhaus and Evan Fox-Decent have noted, this approach has a certain logic: "One should not throw good money after bad." ${ }^{\mathrm{g} 7}$ Judges effectively washed their hands of responsibility for the fairness of administrative procedures, leaving such questions up to Parliament.

After the Second World War, however, in the context of a growing welfare state, British commentators began to argue that judges should review the procedural aspects of administrative functions as well. The distinction between administrative and judicial or quasi-judicial functions was criticized as artificial. ${ }^{88}$ By the mid-1960s, British courts had accepted that decision makers had a duty to be procedurally fair even when carrying out administrative functions. ${ }^{99}$

The SCC endorsed the doctrine of procedural fairness in the 1979 Nicholson case. The Court held that administrative decision makers were under a duty to act fairly, regardless of whether the function in question could be classified as "administrative" or "quasi-judicial" ${ }^{0}$ In doing so, the Court signalled the obsolescence of the older formal categories and the extension of judicial scrutiny to a wider variety of functions. In subsequent cases, the Court clarified that an obligation of procedural fairness generally arises in any public decision

que les règles fondamentales de justice doivent être respectées, il faut se garder d'imposer un code de procédure à un organisme que la loi a voulu rendre maitre de sa procédure" at 176). See also Re Cedarvale Tree Services Ltd and Labourers' International Union of North America, Local 183, [1971] 3 OR 832, 22 DLR (3d) 40 (CA) [cited to OR] ("[i]t is clear to me that under the Labour Relations Act the Board is master of its own house not only as to all questions of fact and law falling within the ambit of the jurisdiction conferred upon it by the Act, but with respect to all questions of procedure when acting within that jurisdiction" at 841, Arnup JA).

87. David Dyzenhaus \& Evan Fox-Decent "Rethinking the Process/Substance Distinction: Baker v Canada" (2001) 51:3 UTLJ 193 at 203.

88. See SA de Smith, supra note 37 at 114-36. See also HWR Wade, Administrative Law (Oxford: Clarendon Press, 1961) at 141-65.

89. See Ridge v Baldwin, [1963] UKHL 2.

90. Nicholson, supra note 47 at para 22. See also DJ Mullan, "Fairness: The New Natural Justice" (1975) 25:3 UTLJ 281. 
that "affects the rights, privileges or interests of an individual". ${ }^{91}$ There are certain exceptions, notably "legislative" decisions (interpreted broadly to include Cabinet appeals) ${ }^{92}$ and (since 2008) decisions related to the employment of public servants who have employment contracts. ${ }^{93}$ The exemption has also been applied to commercial decisions. ${ }^{94}$ Formal categories therefore still play a limited role in procedural review. A court assessing the fairness of an administrative decision must first determine that it crosses the procedural fairness "threshold"; i.e., it must verify that the rights, privileges or interests of an individual are affected and that the decision does not belong to any of the exceptions. However, in a vast range of cases, these threshold criteria are easily satisfied.

Canadian courts' approach to administrative procedures since Nicholson therefore corresponds to what Martin Loughlin has called "active informalism". ${ }^{55}$ In other words, courts have shown a willingness to intervene in agencies' processes, but they have done so on the basis of context-sensitive assessments of fairness rather than all-or-nothing categories. They have gauged the need for procedures in terms of the purposes these procedures might serve.

The Court has reaffirmed the contextual approach to procedures on numerous occasions since 1979. For example, in Knight $v$ Indian Head School Division No 19, the Court dealt with a school board's termination of one of its employees, in a situation where neither the enabling statute nor the employment contract specified any procedure to be followed. A majority of the Court held that the school board was nevertheless subject to a duty to act fairly. Justice L'Heureux-Dubé, writing for the majority, noted that "the concept of procedural fairness is eminently variable and its content is to be decided in the specific context of each case". ${ }^{96}$

91. Cardinal v Director of Kent Institution, [1985] 2 SCR 643 at 653, 24 DLR (4th) 44 [Cardinal].

92. See e.g. Canada (AG) v Inuit Tapirisat et al, [1980] 2 SCR 735, [1980] 2 FCR 735.

93. See Dunsmuir v New Brunswick, supra note 3 at paras 77-117.

94. See e.g. Irving Shipbuilding, supra note 23.

95. Martin Loughlin, "Procedural Fairness: A Crisis in Administrative Law Theory" (1978) 28:2 UTLJ 215.

96. Knight, supra note 82 at 682. See also May v Ferndale Institution, 2005 SCC 82, [2005] 3 SCR 809 (" $[\mathrm{t}]$ he requirements of procedural fairness must be assessed contextually in every circumstance" at para 90); Canada (Attomey General) v Mavi, 2011 SCC 30 at paras 38-42, [2011] 2 SCR 504. 
In IWA $v$ Consolidated-Bathurst Packaging Ltd, decided that same year, the Court continued to emphasize context. ${ }^{97}$ In this case, an employer challenged the Ontario Labour Relations Board's practice of holding a closed-door meeting of all board members to discuss policy issues arising from a particular case. The employer charged that such a practice vitiated the independence of the board members hearing the case and deprived the parties of an opportunity to be heard. A majority of the Court rejected these arguments. Explaining this decision, Gonthier J wrote that "the rules of natural justice do not have a fixed content, irrespective of the nature of the tribunal and of the institutional constraints it faces". ${ }^{98}$

In Bakerv Canada (Minister of CitizenshipandImmigration), L'HeureuxDubé J, with the unanimous support of her colleagues, established a list of factors that courts should consider in order to determine the level of procedural fairness required in any given instance. The list includes factors pertaining to the statutory framework, such as the nature of the decision being made and its place in the statutory scheme..$^{99}$ It also includes casespecific factors such as the importance of the decision to the individual affected and the legitimate expectations of the person challenging the decision. ${ }^{100}$ Moreover, L'Heureux-Dubé J was at pains to emphasize that her list was not exhaustive, ${ }^{101}$ and that "[a]11 of the circumstances must be considered in order to determine the content of the duty of procedural fairness." 102

Such a contextual, fact-sensitive approach to procedural fairness is in principle compatible with correctness review. However, L'HeureuxDubé J concluded her list of factors in Baker by declaring:

[T] he analysis of what procedures the duty of fairness requires should also take into account and respect the choices of procedure made by the agency itself, particularly when the statute leaves to the decision-maker the ability to choose its own procedures, or when the agency has an expertise in determining what procedures are appropriate in the circumstances. While this, of course, is not determinative, important weight must be given to the choice of procedures made by the agency itself and its institutional constraints. ${ }^{103}$

97. [1990] 1 SCR 282, 68 DLR (4th) 524.

98. Ibid at 323-24.

99. Baker, supra note 67 at paras 23-24.

100. Ibid at paras $25-26$.

101. Ibid at para 28.

102. Ibid at para 21.

103. Ibid at para 27 [citations omitted]. 
This "fifth factor" can be interpreted as a call for judicial deference with regard to procedure. Understood as such, it is incompatible with correctness review.

Indeed, in subsequent cases, the Court has sometimes linked Baker's fifth factor to a deferential approach to procedure. For example, in MoreauBérubé, the Court considered a decision of the New Brunswick Judicial Council to remove a judge from office. The judge in question had contested this decision, noting that an inquiry panel had initially recommended a lesser sanction and the Council had not explicitly mentioned the possibility of removal from office at its hearing. Justice Arbour, writing for a unanimous Court, concluded that the Council's failure to explicitly raise the possibility of removal from office was not procedurally unfair. According to Arbour J, "[w] hile the Council might have opted, as part of their procedure, to remind Judge Moreau-Bérubé that the Council would not be bound by any recommendations made by the inquiry panel, they chose not to, and that was within their discretion." ${ }^{104}$ Justice Arbour cited Baker's fifth factor in support of this reasoning. ${ }^{105}$

Likewise, a few years later, in Council of Canadians with Disabilities $v$ VIA Rail Canada Inc Abella J, citing Baker, declared:

Considerable deference is owed to procedural rulings made by a tribunal with the authority to control its own process. The determination of the scope and content of a duty to act fairly is circumstance-specific, and may well depend on factors within the expertise and knowledge of the tribunal, including the nature of the statutory scheme and the expectations and practices of the Agency's constituencies. ${ }^{106}$

The Court has not always interpreted Baker's fifth factor as calling for a significant degree of deference. At times, the Court has considered agencies' procedural choices, while assigning them limited weight. An illustration of this approach can be found in Congrégation des témoins de Jéhovah de St-Jérôme-Lafontaine $v$ Lafontaine (Village). ${ }^{107}$ This judgment dealt with a municipality's refusal to rezone certain land to permit a group of Jehovah's Witnesses to use it as a place of worship.

104. Moreau-Bérubé, supra note 9 at para 81.

105. Ibid.

106. 2007 SCC 15 at para 231, [2007] 1 SCR 650 [Council of Canadians with Disabilities]. 107. 2004 SCC 48, [2004] 2 SCR 650. 
In making its decision, the municipality had failed to give reasons for its decision. Chief Justice McLachlin, writing for a majority of the Court, held that the decision was procedurally unfair. Applying the Baker factors to determine the appropriate level of procedural fairness, McLachlin CJCconcluded that the fifth factor did not carry much weight, given that the municipality had not actually applied its expertise. ${ }^{108}$ Chief Justice McLachlin's interpretation of Baker's fifth factor is an example of what Paul Daly has called "epistemic deference", meaning that a certain amount of weight is accorded to the agency's procedural choices. ${ }^{109}$ Nevertheless, the administrative decision maker is not recognized as having a protected sphere of authority (in other words, "doctrinal deference" is absent). ${ }^{110}$

Aside from the application of Baker's fifth factor, the Court has also reaffirmed the idea that administrative agencies might be considered "masters in their own house" with respect to procedure, ${ }^{111}$ even in the post-Nicholson era. To recognize agencies as "masters in their own house" implies the possibility of doctrinal deference and not just epistemic deference.

The Court's calls for deference in cases such as Baker are thus in tension with its recent endorsement of correctness review. Moreover, lower courts have also deferred to agencies on procedural questions. In practice, Canadian courts tend to defer to agencies on certain kinds of questions, such as whether or not to hold an oral hearing (where none is required by statute). ${ }^{112}$ Courts also typically defer to agencies with regard to the management of hearings and other decision-making

108. Ibid at para 11.

109. Daly, Theory of Deference, supra note 4.

110. See ibid.

111. Prassad $v$ Canada (Minister of Employment and Immigration), [1989] 1 SCR 560 at 568-69, 57 DLR (4th) 663 [Prassad].

112. See e.g. Baker, supra note 67 at paras 33-34; Xwave Solutions Inc $v$ Canada (Public Works \& Government Services), 2003 FCA 301, 310 NR 164 (dealing with the processes used by the Canadian International Trade Tribunal); Nadeau $v$ United Steelworkers of America, 2009 FCA 100,400 NR 246 (dealing with the processes used by the Canadian Industrial Relations Board); Adetunji $v$ Canada (Minister of Citizenship and Immigration), 2012 FC 708 at para 24, 431 FTR 71 (dealing with procedures used by an immigration officer). 
processes on issues such as the consolidation of proceedings, ${ }^{113}$ the size of the panel assigned to a case ${ }^{114}$ or requests for adjournments. ${ }^{115}$

I would like to acknowledge (in order to dismiss) a possible counterargument-a way that one might plausibly argue that deference and correctness review can be reconciled. This counter-argument is based on an analysis of the stages involved in procedural fairness review. Courts and commentators have typically identified two stages of procedural fairness review. The first of these is the "threshold" stage discussed earlier. The second is the "content" stage, in which the judge must determine compliance with the requirements of procedural fairness in the particular circumstances. The calls for deference I have cited, as in Baker, have been confined to the content stage.

The counter-argument, which tries to reconcile deference and correctness, proceeds by breaking down the "content" stage into two substages: one in which the judge determines what procedures were required in the circumstances and another in which the judge determines whether the agency lived up to these requirements. According to this counterargument, deference may be appropriate at the first of these two substages, but not at the second. Indeed, such an analysis is implicit in the passage from Brown and Evans quoted in Ellis-Don. ${ }^{116}$ It is also implicit in LeBel J's statement in Khela, which specified that "the standard for determining whether the decision maker complied with the duty of procedural fairness will continue to be "correctness". ${ }^{117}$ In his academic writings, Huscroft JA made this distinction explicit:

$[T]$ here is some room for deference when it comes to determining the content of the duty of fairness, because the procedural choices made by the decision-maker are one of the considerations courts must take into account. However, once the content of the duty of in a particular context has been determined, the question for the court is simply whether

113. See e.g. McNaught $v$ Toronto Transit Commission (2005), 74 OR (3d) 278, 249 DLR (4th) 334 (CA).

114. See Telus Communications Inc v Telecommunications Workers Union, 2005 FCA 262, 257 DLR (4th) 19. See also Faghihi v Canada (Minister of Citizenship \& Immigration) (1999), 173 FTR 193, 2 Imm LR (3d) 196, aff'd 2001 FCA 163, 274 NR 358.

115. Prassad, supra note 111.

116. Ellis-Don, supra note 16.

117. Khela, supra note 1 at para 79 [emphasis added]. 
the duty of fairness has been met on the facts of the case-a question that will yield a yes or no answer. ${ }^{118}$

However, this separation of the "content" stage into two substages is not generally recognized in case law. It is, in fact, inconsistent with widespread judicial practice. In practice, courts seldom distinguish their standard-setting exercise from their determination of compliance with the standards they have set. Courts often determine the content of procedural fairness by way of reference to the procedures actually employed by the agency: first examining the procedures, then asking if they were fair in the circumstances. Standards of procedural fairness are thus reverse engineered from administrative practices rather than set out in advance.

Moreover, the requirements of procedural fairness are generally understood to establish minimum standards. ${ }^{119}$ Agencies are free to exceed these standards if they so choose, offering greater procedural protections to those subject to the law. A court determining compliance with procedural fairness requirements will not seek to determine whether the decision maker arrived at the one and only right answer to the question; it will instead seek to determine whether the procedures employed by the decision maker met or exceeded a minimum standard. ${ }^{120}$

118. Grant Huscroft, "From Natural Justice to Fairness: Thresholds, Content and the Role of Judicial Review" in Colleen M Flood \& Lorne Sossin, eds, Administrative Law in Context, 2nd ed (Toronto: Emond Montgomery, 2013) 147 at 182. It is interesting that Huscroft JA failed to make this same distinction at another point in the same article: "It is important to emphasize that courts require decisions about threshold and content of the duty of fairness to be made correctly. If they are not, the substantive decision made in a particular matter will be quashed and remitted to be made in accordance with the appropriate procedures." Ibid at 153. 119. See e.g. Nicholson, supra note 47 at 328; Cardinal, supra note 91 at 660 .

120. There are also substantive provisions that take the form of minimum standards rather than clear-cut rules. For example, in Britain, the Monopolies and Mergers Commission was empowered to investigate mergers where the companies involved supplied at least $25 \%$ of a particular kind of service "in a substantial part of the United Kingdom." The Commission investigated the merger of two bus companies serving an area representing $1.65 \%$ of the United Kingdom's land area and 3.2\% of its population. The companies argued that this area was not "substantial". The House of Lords treated this as a question of law, but it noted the vagueness of the statutory provision and held that the question was whether the Commission's interpretation fell within a "spectrum of possible meanings", rather than whether the Commission had given the one and only correct answer. See $R v$ Monopolies and Mergers Commission, ex parte South Yorkshire Transport Ltd, [1994] ECC 231 (Eng). 
For example, in Council of Canadians with Disabilities, the Court considered whether the Canadian Transportation Agency had breached the requirements of procedural fairness when it ordered Via Rail to retrofit certain rail cars to make them wheelchair accessible. The Agency had issued this order without waiting for Via Rail to provide estimates of the costs of such a modification. In holding that the Agency's decision was nonetheless procedurally fair, Abella J concluded:

The Agency, following its multi-year dealings with the parties, was in the best position to control its own process with a view to the bona fides and strategic choices of the parties. There are no grounds for a reviewing court to interfere with the Agency's discretion to release its final decision without waiting for VIA to produce the cost estimates. ${ }^{121}$

Indeed, in many cases, courts have followed such an approach despite paying lip service to a correctness standard. For example, in Uniboard Surfaces Inc v Kronotex Fussboden GmbH and Co KG, Décary JA of the Federal Court of Appeal declared that "the determination of the content of the duty of procedural fairness in any given case is a question of law and is reviewable under the standard of correctness", ${ }^{122}$ but then went on to defer to the Canada Border Services Agency's refusal to disclose the report of its investigation into the alleged dumping by European countries. In Thamotharem $v$ Canada (Minister of Citizenship and Immigration), the same court invoked a correctness standard, but ultimately upheld the fairness of the Immigration and Refugee Board's guidelines with regard to the sequence of questioning in refugee status determination hearings. ${ }^{123}$ A more recent example can be found in a decision by the Quebec Court of Appeal in a matter of professional discipline. In Murphy c Chambre de la sécurité financière, a financial advisor who was held to have defrauded his clients applied for judicial review of the decision of the Chambre de la sécurite financière. ${ }^{124}$ The Court of Appeal agreed with the parties that the procedures employed by the Chambre should be reviewable on a

121. Council of Canadians with Disabilities, supra note 106 at para 245.

122. 2006 FCA 398 at para 6, [2007] 4 FCR 101 [Uniboard].

123. 2007 FCA 198 at paras 33, 51, 366 NR 301.

124. 2010 QCCA 1079, 89 CCLI (4th) 51. 
correctness standard. Nevertheless, the court deferred to the Chambre's procedural choices. ${ }^{125}$

It must be acknowledged, however, that courts sometimes treat procedural fairness as a matter of clear-cut rules rather than variable standards. In such cases, courts may insist on correctness in the application of these rules, at the expense of deference in the determination of the content of procedural fairness. Such an approach is visible in Syndicat des salariés de Béton St-Hubert-CSN c Béton St-Hubert. ${ }^{126}$

This case arose from a situation in which a worker had allegedly made threats against his co-workers. Dismissed, the worker filed a grievance. The employer asked the grievance arbitrator to allow the co-workers (the targets of the alleged threats) to testify anonymously; the arbitrator agreed. On appeal, the Quebec Court of Appeal held that allowing anonymous testimony would be procedurally unfair. Although it opined that labour arbitrators should have a great deal of flexibility with regard to process, it held that the identities of the witnesses must be divulged in order to have a proper adversarial process. The court explicitly invoked a correctness standard. Correctness review is also found in other provinces and in the context of other administrative regimes. For example, the Alberta Court of Appeal applied a correctness standard when a medical review panel cut off an employee's disability benefits without considering his written submissions. ${ }^{127}$ The same court applied a correctness standard when the city of Edmonton, assessing property tax, failed to promptly notify the property owner that the information it had provided was insufficient. ${ }^{128} \mathrm{In}$ both cases, the court declared the relevant procedures to be procedurally incorrect.

125. For additional examples of correctness review observed only in the breach, see Irving Shipbuilding, supra note 23 at paras 26, 45; Nova Scotia (Community Services) v NNM, 2008 NSCA 69 at para 40, 268 NSR (2d) 109 [NNM]; Bowater Mersey Paper Co v Communications Energy and Paperworkers Union of Canada, Local 141 (2010), 289 NSR (2d) 351 at paras 28, 32, 3 Admin LR (5th) 261 (CA) [Boweter].

126. 2010 QCCA 2270, [2011] RJDT 19. See also Syndicat des travailleuses et travailleurs de l'Hôtel Méridien de Montréal c Guilbert, 2012 QCCS 1984, 2012 CarswellQue 4490 (WL Can).

127. See Edmonton Police Association v Edmonton (City of), 2007 ABCA 184, 283 DLR (4th) 695 .

128. See Boardwalk Reit LLP $v$ Edmonton (City), 2008 ABCA 220 at paras 171-74, 299 DLR (4th) 332 . 
I would therefore acknowledge that correctness review accurately describes Canadian courts' approach to procedural fairness in some cases. In these cases, the determination of compliance crowds out any deference in the determination of the content of procedural fairness requirements. There is therefore an unresolved tension in the law. The Federal Court of Appeal explicitly acknowledged this tension in a 2014 judgment. In Re:Sound v Fitness Industry Council of Canada, Evans JA surmised that "[ $[$ ]here is a degree of tension implicit in the ideas that the fairness of an agency's procedure is for the courts to determine on a standard of correctness, and that decision-makers have discretion over their procedure. ${ }^{p 29}$

\section{Is Correctness Review of Procedures Justified?}

Should administrative procedures be subject to a correctness standard? Indeed, should administrative procedures be subject to judicial review at all? Various normative arguments can be offered in favour of correctness review of procedures. However, I argue in this Part that there are also convincing arguments for judicial deference on procedural questions, at least in some cases. The uniform application of a correctness standard to procedural questions would appear to be inappropriate.

Some of the arguments in favour of correctness review are essentially formal, based on the idea of respect for law. One argument is that the rules of procedural fairness or natural justice are legal rules and that courts are therefore responsible for ensuring that they are respected. As Abella $\mathrm{J}$ wrote for a unanimous Court in Newfoundland and Labrador Nurses' Union v Newefoundland and Labrador (Treasury Board), "the breach of a duty of procedural fairness is an error in law". ${ }^{130}$ This characterization of procedural questions as legal questions implicitly invokes the formal and institutional justifications typically offered for correctness review of substantive legal questions, as discussed in Part II.

However, the fact-intensive nature of procedural fairness analysis makes this characterization uncertain. As I have explained in the previous Part, courts' analyses of the fairness of administrative procedures often

129. 2014 FCA 48 at para 39, [2015] 2 FCR 170 [Re:Sound].

130. 2011 SCC 62 at para 22, [2011] 3 SCR 708 [Newfoundland Nurses]. See also Uniboard, supra note 122 at para $6 ; N N M$, supra note 125 at para 40; Boteater, supra note 125 at para 28. 
begin with a contextual analysis of the procedures used; courts will then ask whether these procedures were, on the whole, fair. Even where courts approach procedural fairness as a matter of compliance with rules, the inquiry is likely to be fact-intensive. Such an analysis is better characterized as a mixed question rather than a pure question of law. As lacobucci J put it in Canada (Director of Investigation and Research) $v$ Southam Inc, a mixed question is a question "about whether the facts satisfy the legal tests". ${ }^{131}$

Diceyan constitutional theory, based on parliamentary sovereignty and the rule of law, supplies an additional formal argument for correctness review when it comes to statutory procedural requirements. When courts ensure respect for these procedures, they are ensuring respect for legislation. However, as Paul Daly emphasizes, respect for legislative intent can also be an argument in favour of deference. ${ }^{132}$ Legislators sometimes explicitly grant agencies discretion with regard to their procedures. For example, in Council of Canadians with Disabilities, Abella J began her procedural fairness analysis by noting that "Parliament entrusted the Agency with extensive authority to govern its own process." 133 This statutory grant of power was one of the factors that led her to conclude that deference was in order.

In other cases, legislators may have indicated their intention in a more general way, such as through the use of a privative clause. For example, in Bibeault v McCaffrey, the Court upheld the Quebec Labour Tribunal's determination that certain employees were ineligible to testify because they did not qualify as "interested parties" under the terms of the statute. ${ }^{134}$ Justice Lamer, as he then was, writing for a unanimous Court, held that the strong privative clause in the statute extended to the question of who qualified as an "interested party"; given this privative clause, courts should not intervene. ${ }^{135}$ This formal justification for deferential review amounts to a reformulation of the idea expressed in some of the older cases, such as Komo Construction Inc c Commission des Relations de Travail du Québec, ${ }^{136}$ that certain questions of natural justice are within the agency's jurisdiction. It bespeaks a judicial concession to clearly expressed legislative will.

131. [1997] 1 SCR 748 at para 35, 144 DLR (4th) 1 [Southam].

132. Daly, "Canada's Bipolar Administrative Law", supra note 2 at 241-42.

133. Supra note 106 at para 230.

134. [1984] 1 SCR 176 at 188, 7 DLR (4th) 1.

135. Ibid at 182, 187.

136. Supra note 42. 
Moreover, as Roderick Macdonald observed, the Diceyan formalist argument for correctness review cannot be extended to implied procedural requirements (derived from the common law). The Diceyan conception of the rule of law emphasizes judicial review as a way of ensuring that state officials respect the limits of their special powers, but it has little to say about the procedures followed by these officials. ${ }^{137}$

If we leave aside the formal legal nature of procedural requirements, there are other essentially institutional (or "practical") $)^{138}$ arguments in favour of correctness review. These arguments are essentially claims about institutional competence. Thus, when courts hold that administrative procedures should be subject to judicial review, they are saying that administrative procedures require oversight and that courts should play this oversight role. When courts hold that administrative procedures must be reviewed according to a correctness standard, they are saying that courts, rather than agencies, should have the last word over administrative procedures.

It is important to distinguish these arguments about institutional competence from arguments for procedural fairness in general. The existence of procedural protections may be justified instrumentally, according to the notion that they are likely to produce better substantive outcomes. Alternatively, procedural protections can be justified on the basis that they have an intrinsic value, understood either in terms of the rights and dignity of the individuals affected or in terms of transparency and accountability of public decision making. ${ }^{139}$ Arguments about judicial oversight and standards of review are independent of this debate about the justification for procedures in general. For the purposes of the standard of review, it does not matter whether procedures are understood in intrinsic or instrumental terms.

These institutional arguments begin with the premise that agencies should not have absolute discretion with regard to their procedures. Agencies may be inclined to sacrifice procedural fairness for the sake of expediency or may lack the institutional capacity to objectively

137. See Macdonald, supra note 38 at 529-30.

138. Daly, Theory of Deference, supra note 4 at 70-136.

139. See generally Carol Harlow \& Richard Rawlings, Law and Administration, 3rd ed (Cambridge, UK: Cambridge University Press, 2009) at 618-21. 
assess the fairness of their own procedures. Administrative procedures should therefore be subject to some kind of external review. However, this argument for external review does not necessarily imply a role for courts. One can imagine other ways of holding agencies accountable for procedural fairness such as through more detailed procedural codes: through ombudsman institutions or through specialized tribunals. ${ }^{140}$ Although the role of courts in overseeing administrative procedures is constitutionally entrenched and unlikely to change soon, it is historically contingent rather than conceptually necessary.

A principled argument for judicial review of administrative procedures therefore requires an additional step: an argument about the role of courts. An argument for judicial review according to a correctness standard, moreover, implies a claim about the relative institutional capacity of courts vis-à-vis agencies. It implies that there is some basis for thinking that courts, rather than agencies, should have "the last word" with regard to administrative procedures.

An institutional argument for correctness review may also be linked to the purportedly "legal" nature of procedural fairness requirements. The Court has sometimes implied that courts possess superior expertise in legal matters. ${ }^{141}$ However, as I have already noted, procedural fairness is said to be a context-sensitive (and thus, fact-intensive) inquiry. In many cases, procedural questions resemble mixed questions of fact and law rather than pure questions of law. It might therefore be said that questions of procedural fairness should be left to the decision maker most familiar with the facts-i.e., the agency responsible for the initial decision.

140. See e.g. Macdonald, supra note 38. Macdonald recommends creating a board composed of persons possessing specialized expertise in each of the different kinds of processes employed in contemporary public administration: "custom, officially declared law, adjudication, voting, managerial direction, contract, mediation, property and deliberate resort to chance". Ibid at 19. This board would hear appeals regarding procedural fairness and its remedies would emphasize mediation and prospective reforms. Macdonald's classification of administrative functions is derived from Lon Fuller. See generally Lon L Fuller, "The Forms and Limits of Adjudication" (1978) 92:2 Harv L Rev 353. 141. Pushpanathan, supra note 50 at para 37; Dunsmuir v New Brunswick, supra note 3, Deschamps J ("superior courts have a core expertise to interpret questions of law" at para 162). 
An alternative institutional argument for correctness review could be grounded on courts' relative expertise with regard to the procedures themselves. Judges are experts in matters of adjudication. Their everyday work requires them to oversee the precise details of adjudicative processes, including issues such as the use of interim measures, the disclosure of evidence, questions of standing and representation by counsel, the assessment of the admissibility of evidence and the relative weight to be accorded to it, the management of delays, and the awarding of costs. One might argue that judges should have the last word because they possess relative expertise in these matters. However, it is not clear that courts possess expertise relative to administrative decision makers with regard to non-adjudicative processes involving, for example, rule making, funding allocations or the granting of licences. The recognition of a flexible, context-sensitive duty of fairness, generally applicable to most kinds of administrative decision making-and not just judicial or quasi-judicial decisions-therefore undermines this institutional rationale for the application of a correctness standard..$^{142}$

Indeed, one might argue that agencies are better placed than courts to answer certain procedural questions-they are in fact more expert than courts with regard to their own procedures. Such a notion of relative procedural expertise is at the heart of L'Heureux-Dubé J's reasoning in Baker's fifth factor when she notes that an agency may have "an expertise in determining what procedures are appropriate in the circumstances.".143 Notably, however, L'Heureux-Dubé J also appeals to legislative intent, emphasizing that deference is appropriate "particularly when the statute leaves to the decision-maker the ability to choose its own procedures". ${ }^{144}$ The institutional justification also has a prominent place in Abella J's reasoning in Council of Canadians with Disabilities. ${ }^{145}$

Writing in the US context, Adrian Vermeule offers an additional argument for recognizing agencies' relative expertise in matters of procedure. Agencies' procedural choices are intertwined with their substantive mandates. If courts are prepared to grant agencies deference

142. To be more precise, a generalized duty of procedural fairness expands the scope of procedural protection beyond the set of decisions where correctness review could be justified on institutional grounds.

143. Baker, supra note 67 at para 27.

144. Ibid.

145. Supra note 106 at para 231. 
with regard to substance, they should also acknowledge that agencies may be best placed to determine the optimal procedural arrangements for carrying out their substantive mandates. ${ }^{146}$

An analysis of the various normative arguments therefore shows that the strength of these arguments is highly variable. The arguments for correctness review of procedures are strongest where legislators have subjected agencies to "general" procedural rules and manifested an intention to have courts interpret and enforce these rules. They are also stronger in the context of procedures that closely resemble adjudication. These arguments are much weaker where legislators have explicitly or implicitly granted agencies a certain amount of procedural discretion. They are also weaker in non-adjudicative contexts.

\section{Dichotomous Standards of Review and the Ambiguous Boundary Between Process and Substance}

In the previous Parts, I have cast doubt on the SCC's endorsement of correctness review, drawing on formal authorities as well as principled arguments. In this Part, I present yet another argument for skepticism about correctness review of procedures, based on concerns about the coherence of Canadian administrative law as a whole. The Court's recent endorsement of procedural correctness review stands in stark contrast to its move toward deference in substantive matters. This dichotomous (or as Paul Daly calls it, "bipolar") approach to judicial review gives rise to a further set of challenges, given that procedure is not always easily distinguishable from substance. ${ }^{147}$

The argument in this Part is normative in the sense that it is informed by values of legal coherence and predictability; however, these normative concerns largely remain in the background. The bulk of this Part is dedicated to a descriptive argument, aiming to demonstrate the ambiguity of the process/substance distinction and the practical difficulties involved in applying it. This descriptive account implies that correctness review

146. See Adrian Vermeule, "Deference and Due Process" (2015) Harv L Rev Working Paper No 15-12, online: < papers.ssrn.com/sol3/papers.cfm?abstract_id=2611149>.

147. Daly, "Canada's Bipolar Administrative Law", supra note 2. 
of procedures, rigorously applied, would contribute to incoherence and unpredictability; I suggest that this would be an unfortunate development.

The arguments for correctness review are premised on a clear distinction between process and substance. This distinction was perhaps most clearly expressed in CUPE $v$ Ontario, where Binnie J declared that "standards of review" applied only to substantive questions. ${ }^{148}$ Justice Binnie acknowledged some points of overlap between courts' analyses of procedural and substantive questions. However, he declared that, "while there are some common 'factors,' the object of the court's inquiry in each case is different". ${ }^{19}$ This process/substance distinction is crucial because, since Dunsmuir, the Court has held that most substantive questionsincluding many questions of law-are subject to review according to a reasonableness standard. ${ }^{150}$ The majority of the Court in Dunsmuir held that a reasonableness standard should "usually" apply, subject to certain exceptions. These exceptions include "true questions of jurisdiction or vires", questions of law that are "both of central importance to the legal system as a whole and outside the adjudicator's specialized area of expertise" and questions in which courts are required to draw jurisdictional boundaries between two or more agencies. ${ }^{151}$ The general application of a correctness standard to procedural questions thus depends on courts' ability to distinguish these questions from substantive ones.

However, the distinction between process and substance is often ambiguous. ${ }^{152}$ The cases reveal two main types of ambiguity. The first type arises in situations where the agency either based its decision on grounds not raised before the parties or failed to address issues raised by the parties. Such "adjudicative unfairness" may raise doubts about the substance of the decision or may be seen as a form of procedural unfairness. The second type of ambiguity arises from the fact that agencies' procedural choices may be treated as decisions in their own right and reviewed as such. Such process/substance ambiguity means that the standard of review in many cases depends on whether the issues are characterized as procedural or substantive. This state of affairs gives rise to considerable uncertainty.

148. Supra note 10 at para 102.

149. Ibid at para 103.

150. See The Honourable John M Evans, "Triumph of Reasonableness: But How Much Does It Really Matter?" (2014) 27:1 Can J Admin L \& Prac 101 at 103.

151. Dunsmuir v New Brunswick, supra note 3 at paras 53-64.

152. See e.g. Dyzenhaus \& Fox-Decent, supra note 87.

D. McKee 
Moreover, litigants have an incentive to manipulate the process/substance distinction in search of their preferred outcome.

\section{A. Adjudicative Fairness and the Duty to Give Reasons}

Certain aspects of administrative processes are difficult to characterize as procedural or substantive. Brown and Evans call one such aspect "adjudicative fairness"-the notion that decisions must be based on issues debated by the parties rather than other issues. ${ }^{153}$ Closely related is the question of reason giving: an agency's obligation to explain and justify the basis of its decision. Process/substance ambiguity surrounding these aspects of decision making has been a source of uncertainty in Canadian administrative law.

Lon Fuller's theory of adjudication explains the importance of adjudicative fairness. Fuller conceived of adjudication as a model of social ordering in which parties participate through the presentation of proofs and reasoned arguments. From this analysis, Fuller deduced that adjudication, by its very nature, required certain kinds of processes and structures, such as an impartial decision maker as well as proceedings initiated by someone other than the decision maker. Fuller also specified that adjudication implies that the decision must be based on grounds that the parties had an opportunity to address. ${ }^{154}$

The principle that a decision must be based on issues debated by the parties does not apply to every kind of administrative process. There are many processes in which it is appropriate for agencies to base their decisions on "policy" considerations that may not have been fully explored by the parties. This principle is important in processes based on the model of adjudication, however. Given the prevalence of administrative tribunals performing adjudicative functions, it is an issue that often arises in practice.

Where decisions have been based on facts or arguments not debated by the parties, courts have generally held these decisions to be unfair. Sheddy $v$ Law Society of British Columbia, for example, concerned a lawyer who

153. Donald JM Brown \& The Honourable John M Evans, Judicial Reviere of Administrative Action in Canada (Toronto: Carswell, 2014) (loose-leaf 3, 2015 supplement) ch 14:4211 at 67-68.

154. Fuller, supra note 140 at 388. 
was charged with professional misconduct for notarizing a false affidavit. ${ }^{155}$ A law society panel cleared the lawyer of professional misconduct, but held that he was nevertheless guilty of incompetence. The BC Court of Appeal held that the panel had breached the requirements of procedural fairness by deciding the case according to an issue that was not before it. ${ }^{156}$ The same pattern can be observed in Société d'habitation et de développement de Montréal c Syndicat descols bleus regroupés de Montréal, section locale 301 (SCFP/FTQ), in which a labour arbitrator based his decision on a recent judgment that neither party had invoked in its arguments. ${ }^{157}$ Justice Dussault held that it was procedurally unfair for the arbitrator to do so without giving the parties a chance to respond. ${ }^{158} \mathrm{~A}$ similar issue arose in Re:Sound, which dealt with a decision of the Copyright Board concerning the tariff that fitness centres would have to pay to copyright holders for using recorded music. ${ }^{159}$ After holding a hearing on this issue, the Board obtained additional information and used this information as a basis for computing the tariff. The copyright holders contested this use of information that had not been presented at the hearing. Justice Evans ultimately agreed, holding that it was a breach of procedural fairness for the Board to base its tariff on a ground that the parties did not know they needed to address. ${ }^{160}$

155. 2007 BCCA 96, 58 Admin LR (4th) 48.

156. Ibid at para 19.

157. 2005 QCCA 965, [2005] RJDT 1496.

158. Ibid at paras 30-31.

159. Re:Sound, supra note 129.

160. Ibid at para 77. For another example of characterizing the issue this way, see Syndicat des employées et employés professionnels et de bureau, section locale 574, SEPB, CTC-FTQ c Groupe Pages jaunes Cie, 2015 QCCA 918 at paras 38-46, 2015 CarswellQue 4879 (WL Can). This case arose from a dispute between an employer and a union over changes to the employees' pension plan. The decision turned on the interpretation of a letter of agreement between the employer and the union. The arbitrator based his decision on his own interpretation of the letter, which was neither that of the employer nor that of the union. This interpretation had not been raised at the hearing, and the union alleged that the arbitrator's means of arriving at his decision constituted procedural unfairness, reviewable under a correctness standard. Justice Savard held that a correctness standard applied to this question because it was procedural. However, she held that the arbitrator's decision to consider a new interpretation of the letter was not procedurally unfair. She stated that her conclusion would have been different if the arbitrator had considered new legal sources without giving the parties a chance to respond or if one of the parties had been denied the opportunity to present new evidence in response to the new interpretation. Ibid. 
Another kind of adjudicative unfairness may arise when the adjudicator fails to address issues raised by the parties. In such situations, courts have not followed any consistent approach. Some courts have treated these cases as breaches of procedural fairness, reviewable on a correctness standard. For example, in Turner $v$ Canada ( $A G$ ), a spurned applicant for a federal public service job brought a complaint before the Canadian Human Rights Tribunal, alleging discrimination on the basis of race as well as disability. ${ }^{161}$ The Tribunal rejected the allegation of racial discrimination, but its reasons failed to address disability as an alleged ground of discrimination. On judicial review, Turner argued that this failure to address one of his allegations amounted to a breach of procedural fairness. Justice Mainville, writing on behalf of the Federal Court of Appeal, accepted this argument, applying a correctness standard and overturning the Tribunal's decision. ${ }^{162}$

However, an example of the opposite approach can be found in ATCO Gas and Pipelines Ltd $v$ Alberta (Energy and Utilities Board), in which a gas company alleged belatedly (in a reply argument) that the Alberta Energy and Utilities Board had no jurisdiction over certain facilities. ${ }^{163}$ The Board explicitly refused to deal with these jurisdictional arguments. On judicial review, ATCO alleged that this refusal amounted to a breach of procedural fairness. The Alberta Court of Appeal disagreed and held that the Board's refusal to deal with certain issues (if raised belatedly) was within its discretion. ${ }^{164}$

The Federal Court of Appeal reached a similar conclusion in Forest Ethics Advocacy Association v National Energy Board, ${ }^{165}$ which arose from the National Energy Board's hearings on the Enbridge Line 9 pipeline project. The National Energy Board had chosen to focus only on the pipeline itself and not to consider the environmental impact of Alberta oil sands development or the ultimate combustion of the oil carried by the pipeline. Justice Stratas characterized this as a substantive issue, reviewable according to a reasonableness standard.

161. 2012 FCA 159, 431 NR 327.

162. Ibid at paras 38-45. See also Sketchley v Canada (Attorney General), 2005 FCA 404, [2006] 3 FCR 392.

163. 2005 ABCA 226, 48 Alta LR (4th) 1.

164. Ibid at paras 16-21. See also Envoy Relocation Services Inc et al v Canada (Minister of Public Works and Government Services), 2005 FCA 364 at para 7, 341 NR 350.

165. 2014 FCA 245 at paras 63-69, 465 NR 152 [Forest Ethics]. 
In 2015, Stratas JA confronted a similar set of circumstances in Bergeron $v$ Canada $(A G) .{ }^{166}$ In this case, a federal civil servant filed a complaint with the Canadian Human Rights Commission alleging that the government had discriminated against her by failing to accommodate her disability. The Commission assigned an investigator to examine the complaint; the investigator recommended that the complaint be dismissed because Ms. Bergeron could have used other procedures (namely, a labour grievance) to address the issue. The Commission issued a decision in which it adopted the investigator's recommendation. Ms. Bergeron alleged that the Commission's investigation had not been thorough enough, and she argued that this alleged lack of thoroughness was equivalent to procedural unfairness. Justice Stratas accepted, for the sake of argument, that this question was procedural and that it was reviewable on a correctness standard; applying this standard, he rejected Ms. Bergeron's arguments and upheld the Commission's decision. Justice Stratas nevertheless noted the blurriness of the process/substance distinction:

One might also query whether a failure to investigate thoroughly under the Act is a procedural defect, triggering whatever standard of review applies to procedural matters. A decision based on a deficient investigation can be characterized as one that is not substantively acceptable or defensible because it is based on incomplete information, thereby triggering the standard of review for substantive defects governed by Dunsmuir, above. ${ }^{167}$

Justice Stratas described the current state of affairs for procedural review as "a jurisprudential muddle". ${ }^{168}$

Closely related to the question of adjudicative fairness is the question of agencies' duty to give reasons. Indeed, cases in which the decision maker fails to address certain arguments raised by the parties may also be seen as cases about the adequacy of the reasons given. ${ }^{169}$ In Baker, the Court established that common law procedural fairness requirements could, under some circumstances, oblige administrative decision makers to provide reasons. ${ }^{170}$ But the Court also noted that the reasoning

166. 2015 FCA 160, 474 NR 366.

167. Ibid at para 70 .

168. Ibid at para 71 .

169. See e.g. Bell Canada v Amtelecom Limited Partnership, 2015 FCA 126 at paras 24-25, 473 NR 298 [Bell Canada].

170. Baker, supra note 67 at para 43.

D. McKee 
provided by an administrative decision maker plays a key role in the evaluation of the reasonableness of the decision. ${ }^{171}$ The giving of reasons therefore has both procedural and substantive dimensions. The absence or the inadequacy of reasons may be treated as either a procedural or a substantive problem.

Recent case law provides examples of both approaches. For example, in Clifford $v$ Ontario, ${ }^{172}$ a dispute over pension benefits, the Ontario Municipal Employees Retirement System Tribunal issued a ruling, but its reasons were rather telegraphic. The Ontario Court of Appeal declared that compliance with the obligation to give reasons is to be addressed on a correctness standard, as part of the duty of procedural fairness. However, it distinguished compliance with reason giving from an evaluation of the content of reasons. In this case, it held that reasons given were adequate in the circumstances and thus satisfied a correctness standard. ${ }^{173}$

However, the Court took a different approach in Nerefoundland Nurses. ${ }^{174}$ In this case, a union argued that gaps in an arbitrator's reasoning process were such as to amount to an absence of reasons and thus a breach of procedural fairness, reviewable on a correctness standard. The Court, however, drew a distinction between the absence of reasons (which could, in some cases, amount to a breach of procedural fairness) and the giving of fragmentary or substandard reasons (which should be evaluated in terms of the substance of the decision). Nerefoundland Nurses is generally considered to have settled this issue. However, it has settled this issue on the basis of a somewhat tenuous distinction: Where does one draw the line between inadequate reasons and nonexistent reasons? For example, what if an agency provides only generic, boilerplate reasons? ${ }^{175}$ What if it simply copies and pastes from the submissions of the parties? ${ }^{176}$ The artificiality of this distinction illustrates the judicial acrobatics sometimes required in order to maintain the process/substance distinctionand its accompanying dichotomy with regard to standards of review.

171. Ibid at paras $63-65$.

172. 2009 ONCA 670,98 OR (3d) 210.

173. Ibid.

174. Supra note 130 at paras $20-22$.

175. See e.g. Komolafe $v$ Canada (Minister of Citizenship and Immigration), 2013 FC 431, $16 \mathrm{Imm}$ LR (4th) 267.

176. See e.g. University of Alberta $v$ Chang, 2012 ABCA 324, 44 Admin IR (5th) 216 (judicial "cutting and pasting" described at paras 17-18). 


\section{B. Procedural Choices as Decisions}

In CUPE v Ontario, as quoted above, Binnie $\mathrm{J}$ drew a distinction between the "manner" of making a decision and the "end product" of such a process. ${ }^{177}$ In practice, however, such a distinction is not always evident. In some cases, agencies' procedural choices may be treated as decisions in their own right and thus subjected to judicial review according to the standards set out in Dunsmuir. When this happens, such decisions are likely to be characterized either as questions of discretion or as questions of the interpretation of the agency's home statute. In either case, the standard of review applied to these procedural choices will usually be reasonableness. The possibility of treating procedural choices as decisions thus provides a further source of uncertainty as to the applicable standard of review for procedural questions.

Prassad v Canada (Minister of Employment and Immigration) prefigures this trend. That case dealt with an immigration adjudicator's refusal to adjourn an inquiry. The adjudicator was operating under a set of regulations that explicitly stated that the adjudicator "may adjourn the inquiry at any time for the purpose of ensuring a full and proper inquiry". ${ }^{178}$ Justice Sopinka, for the majority, held that the adjudicator had validly exercised his discretion to refuse the request for an adjournment and that such a refusal was not procedurally unfair. By treating this procedural issue as a matter of discretion, the Court was able to justify deference.

Likewise, in Deloitte \& Touche LLP v Ontario (Securities Commission), the Court examined a situation in which the Ontario Securities Commission (OSC) had ordered an accounting firm to disclose its records with regard to a company under investigation. ${ }^{179}$ The Ontario Securities Act gave the OSC broad discretion to order disclosure if it was "in the public interest". ${ }^{180}$ The Court held that the standard of review applicable to the OSC's order was reasonableness and that the disclosure order was in fact reasonable.

177. CUPE v Ontario, supra note 10 at para 102.

178. Prassad, supra note 111 at 567, citing Immigration Regulations, 1978, SOR/78-172, s 35(1).

179. 2003 SCC 61, [2003] 2 SCR 713.

180. Ibid at para 6 . 
A more recent example can be found in the Federal Court of Appeal's decision in Maritime Broadcasting System Ltd $v$ Canadian Media Guild (Maritime Broadcasting), ${ }^{181}$ released just three weeks before Khela. At issue was a labour dispute involving the question of membership in a bargaining unit. The union and the employer both submitted information to the Canada Industrial Relations Board after what was supposed to have been the final date for submissions. Upon judicial review, the employer argued that it had not had a proper opportunity to respond to the union's final submissions. Justice Stratas noted that administrative procedures are subject to a certain amount of discretion. He concluded that procedural fairness could be assessed according to a reasonableness standard and that the procedures used in this case were in fact reasonable. ${ }^{182}$

In some cases, statutes stipulate explicit procedural rules rather than granting agencies discretion over procedures. In Dunsmuir, the Court held that agencies' interpretations of their home statutes will generally be entitled to deference. ${ }^{183}$ The Court reinforced this guideline in subsequent cases, turning it into a presumption. ${ }^{184}$ This presumption implies that agencies' procedural choices, if derived from agencies' interpretations of their home statutes, are reviewable according to a reasonableness rather than a correctness standard. For example, in Alberta Teachers Association, the Court considered the fact that the Alberta Information and Privacy Commissioner had extended the timeline for its own inquiry beyond the ninety-day period specified in the statute. A majority of the Court held that this was essentially a question of statutory interpretation, one specific to the administrative regime in question and within the decision maker's expertise. A reasonableness standard therefore applied, and the decision was held to be reasonable. ${ }^{185}$

181. 2014 FCA 59, 455 NR 115 [Maritime Broadcasting].

182. Ibid at paras 46-65. Justice Stratas also challenged Binnie J's statement in Khosa, supra note 19, to the effect that Dunsmuir dictates a correctness standard for procedural issues: "Dunsmuir did not actually do that." Ibid at para 53. Note that Stratas JA's two colleagues on the bench, Webb JA and Near JA, concurred in the result but rejected Stratas JA's choice of a reasonableness standard. Ibid at para 74. See also Forest Ethics, supra note 165 (Stratas JA's decision).

183. Dunsmuir, supra note 3 at paras $53-55$.

184. See e.g. Alberta Teachers' Association, supra note 21 at para 39; Rogers, supra note 59 at para 11. But see Evans, supra note 153 at 107-11.

185. Supra note 21. 
Similar reasoning can be seen at work in Syndicat des employés d'Au Dragon forgé inc c Commission des relations du travail ( $A$ u Dragon forgé), a 2013 decision of the Quebec Court of Appeal. ${ }^{186}$ In this case, two unions were competing to be recognized as the bargaining agent for a group of restaurant workers and each sought access to the other's membership list. The Commission des Relations du Travail refused to disclose the lists, citing section 36 of the Quebec Labour Code, which stipulates that union membership must remain confidential. The reviewing judge held that this confidentiality gave rise to a violation of the audi alterem partem principle, reviewable on a standard of correctness. ${ }^{187}$ However, the Quebec Court of Appeal overturned the reviewing judge's decision as well as the application of a correctness standard. Justice Bich reasoned that what was at stake in this case was not procedural fairness in general, but rather procedural fairness in a particular legislative context, and that the Commission des Relations du Travail was therefore entitled to deference. ${ }^{188}$

\section{Justifications for Dichotomous Standards of Review}

The SCC has yet to offer any rationale for the dichotomy between the standards of review applicable to procedural and substantive questions. However, I would speculate that part of the explanation lies in an assumption that procedural questions involve more formal legal analysis-and less "policy" analysis-than substantive questions. I argue that such an assumption is unwarranted.

186. Syndicat des travailleuses et travailleurs de ADF-CSN c Syndicat des employés d'Au Dragon forgé inc, 2013 QCCA 793, [2013] RJQ 831 [Au Dragon forgé].

187. 2011 QCCS 3202, DTE 2011T-493.

188. Au Dragon forgé, supra note 186 at para 47. Interestingly, Bich JA drew an analogy with Doré v Barreau du Québec, 2012 SCC 12, [2012] 1 SCR 395 [Dore], which dealt with the issue of discretionary decisions that infringe Charter rights. In Doré, the SCC held that the justification of an infringement under section 1 of the Charter can be examined by the reviewing judge as part of the analysis of the reasonableness of the decision. Ibid at paras 57-58. In other words, per Dunsmuir, supra note 3 at para 58, the presence of a constitutional issue does not automatically attract a correctness standard. Similarly, Bich JA reasoned that an administrative decision maker may be entitled to deference in determining how the rules of procedural fairness should apply in a particular statutory context. Arguably, Bich JA could have simply held that section 36 of the Labour Code, as a statutory provision, trumps common law rules of procedural fairness. The analogy with Doré was not necessary to the decision in Au Dragon forgé. 
Courts' hands-off approach to substance reflects a recognition that administrative law touches on highly sensitive questions of social and economic regulation, questions that courts are sometimes ill-equipped to answer. In National Corn Growers Assn v Canada (Import Tribunal), Wilson J referred to

a growing recognition on the part of courts that they may simply not be as well equipped as administrative tribunals or agencies to deal with issues which Parliament has chosen to regulate through bodies exercising delegated power, e.g., labour relations, telecommunications, financial markets and international economic relations. Careful management of these sectors often requires the use of experts who have accumulated years of experience and a specialized understanding of the activities they supervise. ${ }^{189}$

Not only do such questions sometimes call for specialized expertise, they may also be highly political, requiring judges to choose among legal interpretations more favourable to business, labour or consumers, for example. Procedural questions appear to be more politically neutral. As Peter Cane has suggested, courts' emphasis on procedural correctness thus "expresses the conviction that people who cannot agree about ends may nevertheless agree about means". ${ }^{190}$

However, the idea that procedural matters are less "political" than substantive questions-and thus more appropriate for correctness review-is rather dubious. Administrative processes, like other legal processes, tend to structure how decision makers understand issues, and they allocate advantages and disadvantages to particular individuals or groups. The Court's dichotomous approach-a hands-off approach to substance, combined with strict, hands-on control of procedures-may thus be based on a misleading image of neutrality.

The permeability of the process/substance distinction, combined with the Court's dichotomous approach to standards of review thus generates further doubts about correctness review of procedures. In practice, this ambiguity has given rise to inconsistency. Courts are placed in the awkward position of drawing boundaries between process and substance in order to determine which standard of review should apply.

189. [1990] 2 SCR 1324 at 1336,74 DLR (4th) 449.

190. Peter Cane, "Review of Executive Action" in Peter Cane \& Mark Tushnet, eds, The Oxford Handbook of Legal Studies (Oxford: Oxford University Press, 2003) 146 at 156. 
Parties seeking to contest decisions have an incentive to frame their grievances in procedural rather than substantive terms. Yet no convincing rationale is offered for such a dichotomous approach and its accompanying unpredictability.

\section{Toward a Better Approach}

This article is meant as a critique of an across-the-board application of a correctness standard to procedural questions. In this final Part, I would like to offer some preliminary thoughts tow ard a new approach. At the same time, I will comment on the most elaborate alternative offered to date: Paul Daly's proposal that procedural questions be incorporated within the Dunsmuir framework. ${ }^{191}$

In my view, any new approach to judicial review for procedural questions should be based on the considerations of principle that I have identified, including legislative intent as well as relative institutional capacities. In light of these considerations, the arguments for judicial scrutiny of procedures are stronger in some cases than others. For example, the arguments are stronger where such scrutiny is implicitly or explicitly invited by statute; where the procedural protections at issue are derived from "general" sources (such as the common law or general procedural codes); or where the administrative process in question closely resembles adjudication. Conversely, more judicial deference is warranted where the legislature has implicitly or explicitly sought to make an agency master of its own procedure, where the procedural issues are confined to the idiosyncrasies of a particular statutory scheme, or where the underlying administrative process consists of forward-looking, discretionary or polycentric policy decisions.

I therefore agree with Daly, Vermeule and others that courts should assume a deferential stance-i.e., that they should apply a reasonableness standard-when they review administrative procedures. Courts should begin by trying to understand agencies' procedural choices, determining whether these choices are susceptible of some rational justification. They should consider the reasons that agencies have given or could have given for their procedural choices.

191. See Daly, “Canada's Bipolar Administrative Law”, supra note 2. 
The application of a reasonableness standard to administrative procedures need not mean judicial abdication. The deferential approach I have in mind is consistent with David Dyzenhaus's notion of "deference as respect", ${ }^{192}$ as endorsed in Baker ${ }^{193}$ and Dunsmuir. ${ }^{194}$ Courts can adopt a robust approach to reasonableness analysis. Procedures and interpretations that go against the grain of legislative intent, inconsistent applications of general procedural rules or major departures from adjudicative integrity are all good reasons for holding that an agency's procedures were unreasonable. Such an approach to judicial review of administrative procedures is consistent with widespread judicial practice. As I have noted, reviewing courts often approach procedural questions as they would approach questions of mixed fact and law, considering how abstract legal norms apply in particular circumstances. They often consider agencies' procedural choices in particular circumstances before going on to determine whether these procedures made sense. The approach I am proposing would essentially describe this approach for what it is: reasonableness review.

Reasonableness should not only be the presumptive standard when courts review administrative procedures, it should be the only standard. A robust approach to reasonableness review would be capable of incorporating the factors that underlie arguments for correctness review, including rule of law considerations as well as the respect for courts' expertise in matters of adjudication. Such an approach has the additional advantage of obviating the need for a two-step approach, in which courts must first determine the standard of review and then apply it. ${ }^{195}$

192. "The Politics of Deference: Judicial Review and Democracy" in Michael Taggart, ed, The Province of Administrative Law (Oxford: Hart Publishing, 1997) 279 at 286.

193. Baker, supra note 67 at para 65.

194. Dunsmuir v New Brunswick, supra note 3 at para 48.

195. As this article went to press, I became aware of a remarkable piece of extrajudicial writing by Stratas JA of the Federal Court of Appeal: The Honourable Justice David Stratas, "The Canadian Law of Judicial Review: A Plea for Doctrinal Coherence and Consistency", 42:1 Queen's IJ [forthcoming in Fall 2016]. In this article, Stratas JA suggests that Canadian administrative law could be improved by eliminating standards of review altogether and simply focusing on the variable margin of appreciation that courts should grant administrative agencies in matters of process as well as substance. Ibid. I am sympathetic to Stratas JA's proposal. Although I have framed my recommendation in terms of a reasonableness standard, I think Stratas JA is right to suggest that a reformminded SCC might want to go even further. 
I am sympathetic to Daly's proposal for the "fusion" of procedural and substantive standards, but I have certain reservations about such an approach. ${ }^{196}$ Building on the work of judges such as Bich JA (in $A u$ Dragon forgê) and Stratas JA (in Maritime Broadcasting), Daly has shown how standards of review for procedural questions might be determined according to the Dunsmuir framework. According to such an approach, courts would presumptively apply a reasonableness standard to procedural questions corresponding to the categories set out in Dunsmuir: procedural questions involving fact, discretion, or policy; procedural questions of mixed fact and law; and procedural questions involving the interpretation of the agency's home statute. This approach would allow courts to exhibit deference on most procedural questions, consistent with the SCC's obiter from Baker and Khela. However, courts would still be able to invoke a correctness standard with regard to questions corresponding to the categories set out in Dunsmuir, including jurisdictional questions and questions of general law.

Such a reform would have the advantage of harmonizing standards of review for procedural and substantive questions. It would recognize the fact that there is no clear conceptual separation between these two types of questions. It would also eliminate the uncertainties I identified in Part IV, above. In principle, such a harmonization should be possible. The factors I have identified for procedural review have all been identified by the Court as relevant to the standard of review for substantive questions, including legislative intent, ${ }^{197}$ the generality or particularity of legal questions ${ }^{198}$ and the distinction between binary and polycentric decision making. ${ }^{199}$ Weaving together these strands of case law presents practical challenges, but no conceptual problems.

However, such an approach would also have its shortcomings, as Daly himself has intimated. ${ }^{200}$ It would place an additional burden on the Dunsmuir framework for determining the standard of review. This framework has been widely criticized, both for its vagueness and its

196. Daly, "Canada's Bipolar Administrative Law", supra note 2.

197. Pushpanathan, supra note 50 at paras 30-31; Dunsmuir, supra note 3 at paras 52, 55.

198. Dunsmuir v New Brunswick, supra note 3 at para 60.

199. Pushpanathan, supra note 50 at para 36; Dunsmuir, supra note 3 at paras 135-36.

200. Daly, "Canada's Bipolar Administrative Law", supra note 2, n 139.

D. McKee 
conceptual instability. ${ }^{201}$ In recent years, the Court has itself displayed a certain ambivalence toward certain aspects of the Dunsmuir framework, notably toward some of the categories of questions that are meant to attract a correctness standard. As I have noted, the Court has come close to eliminating the category of jurisdictional questions, ${ }^{202}$ and the Court has shown itself reluctant to identify questions of general law in cases where it might have done so. ${ }^{203}$

The Dunsmuir framework also assigns a limited role to one factor that I have identified as crucial: the diversity of institutions and processes that make up the contemporary administrative state. ${ }^{204}$ Considerations of institutional diversity may play a role in determining the standard of review under the Dunsmuir approach, either through the use of precedents ${ }^{205}$ or

201. See e.g. David Mullan, "Dunsmuir v New Brunswick, Standards of Review and Procedural Fairness for Public Servants: Let's Try Again!" (2008) 21:2 Can J Admin L \& Prac 117; Gerald P Heckman, "Substantive Review in Appellate Courts since Dunsmuir" (2009) 47:1 Osgoode Hall IJ 695; Matthew Lewans, "Deference and Reasonableness Since Dunsmuir" (2012) 38:1 Queen's LJ 59; Audrey Macklin, "Standard of Review: Back to the Future" in Flood \& Sossin, supra note 118 at 279. Daly has himself made important contributions to this critical literature. See e.g. Paul Daly, "The Unfortunate Triumph of Form Over Substance in Canadian Administrative Law" (2012) 50:2 Osgoode Hall LJ 317; Paul Daly, "Dunsmuir's Flaws Exposed: Recent Decisions on Standard of Review” (2012) 58:2 McGill LJ 483.

202. See e.g. Alberta Teachers' Association, supra note 21 at paras 33-43, Rothstein J.

203. See e.g. Canada (Canadian Human Rights Commission) v Canada (Attorney General), 2011 SCC 53, [2011] 3 SCR 471; Nor-Man Regional Health Authority Inc v Manitoba Association of Health Care Professionals, 2011 SCC 59, [2011] 3 SCR 616; Communications, Energy and Paperworkers Union of Canada, Local 30 v Irving Pulp \& Paper, Ltd, 2013 SCC 34, [2013] 2 SCR 458 [Iroing Pulp \& Paper].

204. The Dunsmuir framework has been held to apply to all kinds of administrative decision makers. There was initially some ambiguity on this point. While addressing administrative decisions in general, the majority reasons in Dunsmuir focus on administrative tribunals. See Dunsmuir v New Brunswick, supra note 3 at paras 1, 33, 47, $54,59,64$. See also Binnie J's criticisms of the majority reasons ibid at paras 120-23, 134 . However, this ambiguity has since been dispelled. See e.g. Catalyst Paper Corp $v$ North Cowichan (District), 2012 SCC 2, [2012] 1 SCR 5; Canadian National Railway Co v Canada (Attorney General), 2014 SCC 40 at paras 53-54, [2014] 2 SCR 135.

205. Dunsmuirv New Brunswick, supra note 3 at para 57. For illustrations of this approach, see Northrop Grumman Overseas Services Corp v Canada (Attorney General), 2009 SCC 50 at 10, [2009] 3 SCR 309; Agraira $v$ Canada (Public Safety and Emergency Preparedness), 2013 SCC 36 at para 49, [2013] 2 SCR 559; Irving Pulp \& Paper, supra note 203 at para 7. 
through the vestiges of the old "pragmatic and functional approach". ${ }^{206}$ Nevertheless, these considerations generally play a secondary role, compared to the law/fact distinction and the application of the "correctness" categories. I would speculate that the application of the Dunsmuir analysis to procedural questions will highlight the difficulties of recognizing institutional diversity under this framework.

Finally, the Dunsmuir framework also places too much emphasis on the law/fact distinction, a distinction that is less relevant in the procedural context. As I have emphasized, most procedural issues, when characterized in terms of the law/fact distinction, will resemble mixed questions of fact and law. Moreover, the law/fact distinction is often malleable. As Binnie J explained in Dunsmuir, under the pragmatic and functional approach, litigants seeking a higher standard had an incentive to reframe mixed questions in more abstract terms, thus extracting "pure" questions of 1aw. ${ }^{207} \mathrm{It}$ would be better to avoid the unnecessary exercise of subjecting procedural questions to the law/fact analysis.

The approach I am recommending also differs significantly from the Baker five-factor test. The appeal of the Baker test is that it makes room, in its fifth factor, for deference to agencies' procedural choices. However, the Baker approach is intended, at least in theory, to enable courts to conduct their own independent determination of the requirements of procedural fairness. It essentially treats deference as an afterthought. As I have noted, courts have sometimes accepted this invitation to decide for themselves what procedural fairness requires, assigning little weight to agencies' procedural choices. In the approach I propose, deference, combined with a robust form of reasonableness analysis, would be the starting point.

206. Dunsmuir, supra note 3 at paras 63-64.

207. Ibid at para 142. For examples of the SCC extracting "pure" legal questions from legal and factual matrices, see Rogers, supra note 59 at para 20; Lévis (City) v Fraternité des Policiers de Lévis Inc, 2007 SCC 14, [2007] 1 SCR 591. For comments on the malleability of the fact/law distinction, see Southam, supra note 131, Iacobucci J. "The distinction between law on the one hand and mixed law and fact on the other is difficult. On occasion, what appears to be mixed law and fact turns out to be law, or vice versa." Ibid at para 35 . See also Morisette JA's comments in Fraternité des policiers de la MRC des Collines-de-l'Outaonais MRC c Mallette, 2010 QCCA 816 at para 27, 4 Admin LR (5th) 74. For another critical reflection on the law/fact distinction, see Clifford Geertz, Local Knowledge: Further Essays in Interpretive Anthropology (New York: Basic Books, 1983) at 167-234. 
What then would be left of the other Baker factors? They would all become part of the reasonableness analysis. In this respect, it is perhaps useful to distinguish the first Baker factor from factors two, three and four. Factors two, three and four (the place of the decision in the statutory scheme, including its finality; the importance of the decision to the persons affected; and legitimate expectations) are all factors that have a direct bearing on the level of procedural protections required. Agencies should be expected to have considered these factors, and courts should hold them accountable for the reasonableness of their choices in this regard. The first factor, however-the extent to which an administrative process resembles adjudication-pertains rather to the relative institutional capacities of agencies and courts. The non-adjudicative nature of an administrative process is a signal to courts that significant deference may be in order.

\section{Conclusion}

The articulation of a correctness standard for questions of procedural fairness raises a number of concerns. From a doctrinal standpoint, it is in tension with the Court's pronouncements in favour of deference. As a matter of principle, there are good arguments for deference, at least with regard to some aspects of administrative procedures. Moreover, the uncertain boundary between process and substance (and the inconsistency of the standards applied to these two types of issues) suggests that correctness review, if consistently applied to procedural questions, would produce incoherent and unpredictable results.

There is no simple answer to the question of how strictly courts should control the procedures used by administrative agencies. The appropriate level of scrutiny depends on a number of factors, including concerns for formal legality as well as issues of relative institutional capacity. Moreover, legislative intent can point in either direction, calling for strict supervision or generous deference. The standard of review for questions of procedural fairness should reflect these underlying tensions. I have argued that this analysis is best accomplished through a robust reasonableness analysis. Not only should reasonableness be the default standard for procedural questions-it should be the only standard. Such a reform would help simplify the judicial analysis of administrative procedures. 
I would like to think that the Court's holding in Khela, to the effect that procedural fairness is subject to correctness review, may not be the last word on the issue. The Court has yet to deal with this issue in any depth; most of its statements on this point appear to be passing remarks. And recent judgments of appellate courts show that the tensions underlying procedural fairness analysis are becoming difficult to ignore..$^{208}$ A reassessment of these doctrines would be helpful in terms of theoretical coherence as well as practical guidance.

208. See e.g. Au Dragon forgé, supra note 186; Re:Sound, supra note 129; Maritime Broadcasting, supra note 181; Forest Ethics, supra note 165; Bell Canada, supra note 169. 
